Article

\title{
Oxidative Stress Biomarkers in Erythrocytes of Captive Pre-Juvenile Loggerhead Turtles Following Acute Exposure to Methylmercury
}

\author{
Javier Hernández-Fernández ${ }^{1,2, *}$, Ellie Anne López-Barrera ${ }^{3}{ }^{\mathbb{D}}$, Leonardo Mariño-Ramírez ${ }^{4}$, \\ Pilar Rodríguez-Becerra ${ }^{1}$ and Andrés Pinzón-Velasco ${ }^{5}$ (D) \\ 1 Department of Natural and Environmental Sciences, Faculty of Science and Engineering, Genetics, \\ Molecular Biology and Bioinformatic Research Group-GENBIMOL, Jorge Tadeo Lozano University, \\ Cra. 4 No 22-61, Bogotá 110311, Colombia; mariad.rodriguezb@utadeo.edu.co \\ 2 Department of Biology, Faculty of Sciences, Pontificia Universidad Javeriana, Calle 45, Cra. 7, \\ Bogotá 110231, Colombia \\ 3 Sergio Arboleda University, Institute of Environmental Studies and Services, IDEASA Research \\ Group_IDEASA, Bogotá 111711, Colombia; ellie.lopez@usa.edu.co \\ 4 NCBI, NLM, NIH Computational Biology Branch, Building 38A, Room 6S614M 8600 Rockville Pike, \\ MSC 6075 Bethesda, MD 20894-6075, USA; marino@ncbi.nlm.nih.gov \\ 5 Bioinformatics and Systems Biology Group, National University of Colombia, Calle 45 Cra. 30, \\ Bogotá 111321, Colombia; ampinzonv@unal.edu.co \\ * Correspondence: javier.hernandez@utadeo.edu.co
}

Received: 21 April 2020; Accepted: 19 May 2020; Published: 22 May 2020

\begin{abstract}
This study describes the use of erythrocytes (RBCs) of loggerhead turtles as in vitro models for evaluating their toxicity to methylmercury. Blood samples of loggerhead turtles that were born in the Colombian Caribbean were used. The $\mathrm{LC}_{50}$ of RBCs to methylmercury was determined at $96 \mathrm{~h}$ using methylmercury concentrations of $0.5-100 \mathrm{mg} \mathrm{L}^{-1}$. Next, the viability of the RBCs and the activity of the enzymes superoxide dismutase (SOD), glutathione S-transferase (GST), and lipid peroxidation by malondialdehyde (MDA) at 6 and $12 \mathrm{~h}$ of exposure to acute concentrations of 0 , 1 , and $5 \mathrm{mg} \mathrm{L}^{-1}$ were evaluated. The $\mathrm{LC}_{50}$ for loggerhead turtle RBCs was $8.32 \mathrm{mg} \mathrm{L}^{-1}$. The cell viability bioassay of RBCs exposed for $12 \mathrm{~h}$ only showed $100 \%$ cell viability. Increasing in vitro $\mathrm{MeHg}$ concentrations caused a corresponding increase in MDA concentration as well as decreases in the activities of SOD and GST. The RBCs represent an excellent model for ecotoxicological studies and SOD, GST, and MDA are biomarkers of environmental pollution and oxidative stress in loggerhead turtles. This was the first study conducted on loggerhead turtle where the response of RBCs to MeHg-induced oxidative stress is evaluated.
\end{abstract}

Keywords: Cytotoxicity; erythrocytes; methylmercury; malondialdehyde; in vitro; superoxide dismutase

\section{Introduction}

The loggerhead turtle (Caretta caretta) is a marine reptile that is distributed throughout the world; however, its population is in decline and in danger of extinction due to anthropic and environmental causes. The loggerhead turtle is considered to be a sentinel species of environmental pollution due to its longevity and high rate of biomagnification of contaminants [1]. These conditions allow for loggerhead turtles to be used as monitoring units for environmental pollutants. Loggerhead turtles reside in the Mediterranean Sea, and the Atlantic, Indian, and Pacific oceans [2]. In Colombia, the loggerhead turtle is distributed in the departments of Atlántico, San Andrés Archipelago, Providencia and Santa Catalina, La Guajira, Magdalena, and Sucre. It has been reported that some juvenile 
individuals of this species use the Colombian Caribbean as foraging area, where they feed on algae, vascular plants, and invertebrates, such as crabs, mollusks, shrimps, starfish, and jellyfish [3]. It has been estimated that sea turtles can survive for very long periods (more than 50 years), time during which they store tremendously contaminating heavy metals in their tissues. Among them, mercury enters through the digestive tract and it is accumulated [4]. These sea turtles are sensitive to mercury storage due to their life history (prolonged anoxia, longevity, omnivore feeding, aquatic habitat) [4]. In Colombia, the loggerhead turtle is categorized as critically endangered according to the criteria of the IUCN. A 97\% reduction of individuals was reported, from 200 nesting females that arrived per season to the Colombian Caribbean (in 1972) to six per year in the most recent assessment [5]. For this reason, it is important to preserve this specie in order to carry out studies that increase the survival, birth rates, reproductive success, and allow for collecting samples to monitor their health, and support future research [6].

Mercury produces lethal and sublethal effects in wildlife, causing different alterations (immunopathological, carcinogenic, teratogenic, neural, cardiovascular, renal, reproductive, and endocrine) [7-10]. To date, it is known that mercury, interacting with the sulfhydryl groups of cells, generates oxidative stress and alters calcium levels. However, the reaction that it experiences in its methylated state $(\mathrm{MeHg})$, with hundreds of proteins and the changes that they cause, need to be investigated in greater depth in order to understand the adverse effects on embryonic and fetal development, and how it interferes with the normal functioning of the neurological, cardiovascular, and immune systems [11]. Mercury ( $\mathrm{Hg}$ ) has potential for biomagnification in the environment. Its high ecotoxicological risk is due to its biogeochemical behavior, allowing for it to associate with solids, suspended matter, and sediments [10]. In oceans and seas, mercury is present in its inorganic and organic forms, with the methylated form, being methylmercury, the most toxic one $\left(\mathrm{CH}_{3}-\mathrm{Hg}^{1}+\right)$ (MeHg) [12]. MeHg is more toxic than inorganic mercury, and it prevails in the marine food chain. It typically comprises $75-99 \%$ of the total mercury (Hg-T) in organisms [13].

In the Colombian Caribbean, sediment $\mathrm{Hg}$-T concentrations range between 20.6-552.7 $\mu \mathrm{g} \mathrm{L}^{-1}$, with averages around $180-300 \mu \mathrm{g} \mathrm{L}^{-1}$ and peaks of up to $1300 \mu \mathrm{g} \mathrm{L}^{-1}[14,15]$. The threshold effect level of $\mathrm{Hg}-\mathrm{T}$ is $130 \mu \mathrm{g} \mathrm{L}^{-1}$ [15]. It is estimated that the global release of mercury from natural sources, anthropogenic sources, and reemission from past activities is 6000-11,000 tons/year [11]. In particular, anthropogenic sources are believed to account for approximately $80 \%$ of the annual $\mathrm{Hg}$ emission to the environment $[16,17]$.

Methylmercury induces the production of reactive oxygen species (ROS), generating oxidative stress and altering the antioxidant defense system of the cells when it joins the sulfhydryl and selenotiol groups $[18,19]$. It also affects the permeability of phospholipid membranes, by producing porosity, stiffness, and lipid peroxidation [19]. Organisms have an antioxidant metabolic machinery made up of the enzymes glutathione-s-transferase (GST), glutathione peroxidase (GPX), superoxide dismutase (SOD), glutathione reductase (GR), and others, which neutralize free radicals and other ROS and prevent cell damage, to neutralize ROS that is produced by oxidative stress induced by the action of $\mathrm{MeHg}$ [20]. In red blood cells, glutathione in its reduced and oxidized states, together with the coenzyme NADPH, help to restore the $\mathrm{Fe}+{ }^{2}$ state in hemoglobin [21].

Erythrocytes (RBCs), unlike other cell types, have a high affinity for methylmercury [22]. In addition, they express a large amount of enzymatic and non-enzymatic antioxidants allowing for the monitoring of the antioxidant response [23]. RBCs are nucleated in birds, reptiles, fish, and amphibians. These blood cells have been used in environmental studies stress [24-30], and to evaluate the response of xenobiotics in mammals [31-33]. However, hardly any studies have been published where environmental pollutants have been quantified in sea turtles [34,35]. To date, there are no reports of the use of RBCs in specific bioassays in which oxidative stress markers were evaluated for exposure to environmental pollutants in sea turtles.

The present study aims to evaluate the use of erythrocytes (RBCs) of captive loggerhead turtles as a predictive in vitro model of oxidative stress that is produced by acute exposure to different 
concentrations of MeHg. The Median Lethal Concentration $\left(\mathrm{LC}_{50}\right)$ and the viability of the $\mathrm{RBC}$ s were determined and, with this result, the concentrations of the bioassay were selected, evaluating SOD, GST, and Malonaldehyde (MDA) activity. These results provide a novel, non-invasive, cost-effective method for ecototoxicological studies on the negative effects of contamination by methylmercury and other molecules on loggerhead turtle populations.

\section{Materials and Methods}

In this study, loggerhead RBCs were used as an in vitro model for determining the oxidative stress of acute $\mathrm{MeHg}$ concentrations. The RBCs were subjected to a pre-adaptation process to the supplemented MEM culture medium. The $\mathrm{LC}_{50}$ of RBCs to methylmercury was determined at concentrations from 0.5 to $100 \mathrm{mg} \mathrm{L}^{-1}$ for $96 \mathrm{~h}$ of incubation. The determined $\mathrm{LC}_{50}$ was taken into account to assess oxidative stress. The RBCs were subjected to acute concentrations of $\operatorname{MeHg}(0,1$, and $5 \mathrm{mg} \mathrm{L}^{-1}$ ) and incubated at $30^{\circ} \mathrm{C}$. It was evaluated whether the SOD, GST, and MDA activities at 6 and $12 \mathrm{~h}$ after $\mathrm{MeHg}$ exposure can be used as biomarkers of environmental contamination and oxidative stress in loggerhead turtles (Figure 1).

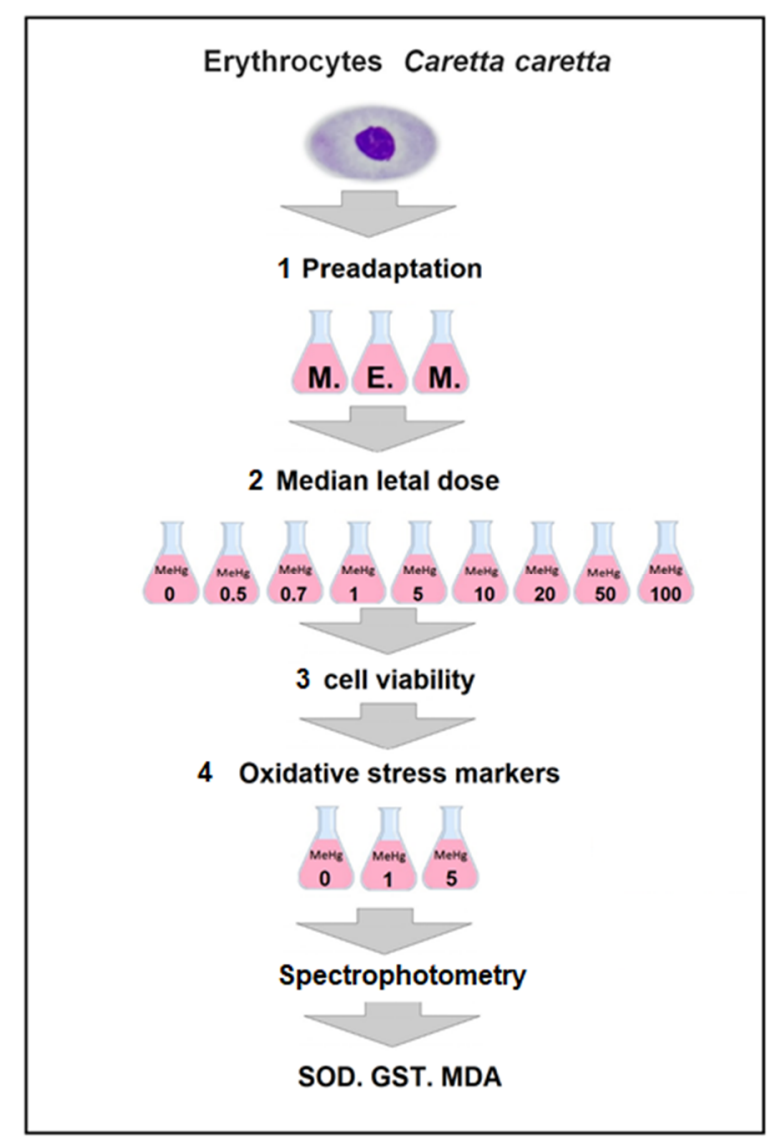

Figure 1. Experimental design. The loggerhead sea turtle erythrocytes were subjected to 1 . Pre-adaptation in supplemented Minimum Essential Medium (MEM) medium, 2. Determination of $\mathrm{LC}_{50}$ in nine doses of methyl mercury, 3. Cell viability determination and 4 . The erythrocytes were subjected to acute doses of methyl mercury and the activities of superoxide dismutase (SOD) and glutathione-s-transferase (GST) enzymes, and the Malonaldehyde (MDA) concentration were measured for spectrophotometry.

\subsection{Study Area, Collection and Analysis of Samples}

The peripheral blood samples were collected from five inmature, apparently healthy, captive-reared pre-juvenile loggerhead sea turtles. The turtles were maintained at ambient temperature (average 
$30{ }^{\circ} \mathrm{C}$, minimum $27^{\circ} \mathrm{C}$ ) in an outdoor seawater pool at the El Rodadero Aquarium in Santa Marta, Colombia $\left(11^{\circ} 13^{\prime} 1.09^{\prime \prime} \mathrm{N}, 74^{\circ} 14^{\prime} 13.75^{\prime \prime} \mathrm{W}\right)$, which was characterized by a semi-arid climate (Figure 2 ). The samples were obtained under a research permit that was granted by the Ministry of Environment and Territorial Development (\#24 of 22 June 2012) and Contract for Access to Genetic Resources (\#64 of 23 April 2013). We also have a permit for the collection of samples of Colombian biodiversity, issued to the Jorge Tadeo Lozano University (Resolution 1271 of 23 October 2014, IDB040I File). The turtles were visually assessed for any injuries to the flippers and carapace. Turtles were considered pre-juveniles due to their development status and Straight Carapace Length (SCL) $<34 \mathrm{~cm}[36,37]$. Turtles were marked, measured, and weighed (Table 1). Blood samples were extracted from the dorsal region of the cervical sinus, in accordance to previously described methodology by Dutton [38]. For the collection of peripheral blood, $4 \mathrm{~mL}$ sterile syringes and $2 \mathrm{~mL}$ tubes with sodium heparin were used. Standard blood tests were performed by Microvet Laboratories, Bogotá D. C., prior to the bioassay in this study, in order to assess the health status of the turtles (Table 1). The total mercury (Hg-T) in RBCs and seawater was analyzed by atomic absorption spectrophotometry at $254 \mathrm{~nm}$ (DMA-80 evo, Milestone-24010 Sorisole (BG), Italy). The $100 \mu \mathrm{L}$ of sample, without any pre-treatment, were introduced into a sample boat, dried through a prescribed method in the DMA-80, and burned at $800^{\circ} \mathrm{C}$. Devolatilized elementary $\mathrm{Hg}$ (Hg vapors) was collected on a gold amalgamation trap and subsequently desorbed for quantification. DMA-80 reaches a detection limit as low as 0.001 nanograms of mercury. Analyses of duplicates and standard reference material were performed to control accuracy and precision. This quantification was carried out at Toxicology Laboratory, COLCAN, and Bogotá D. C.

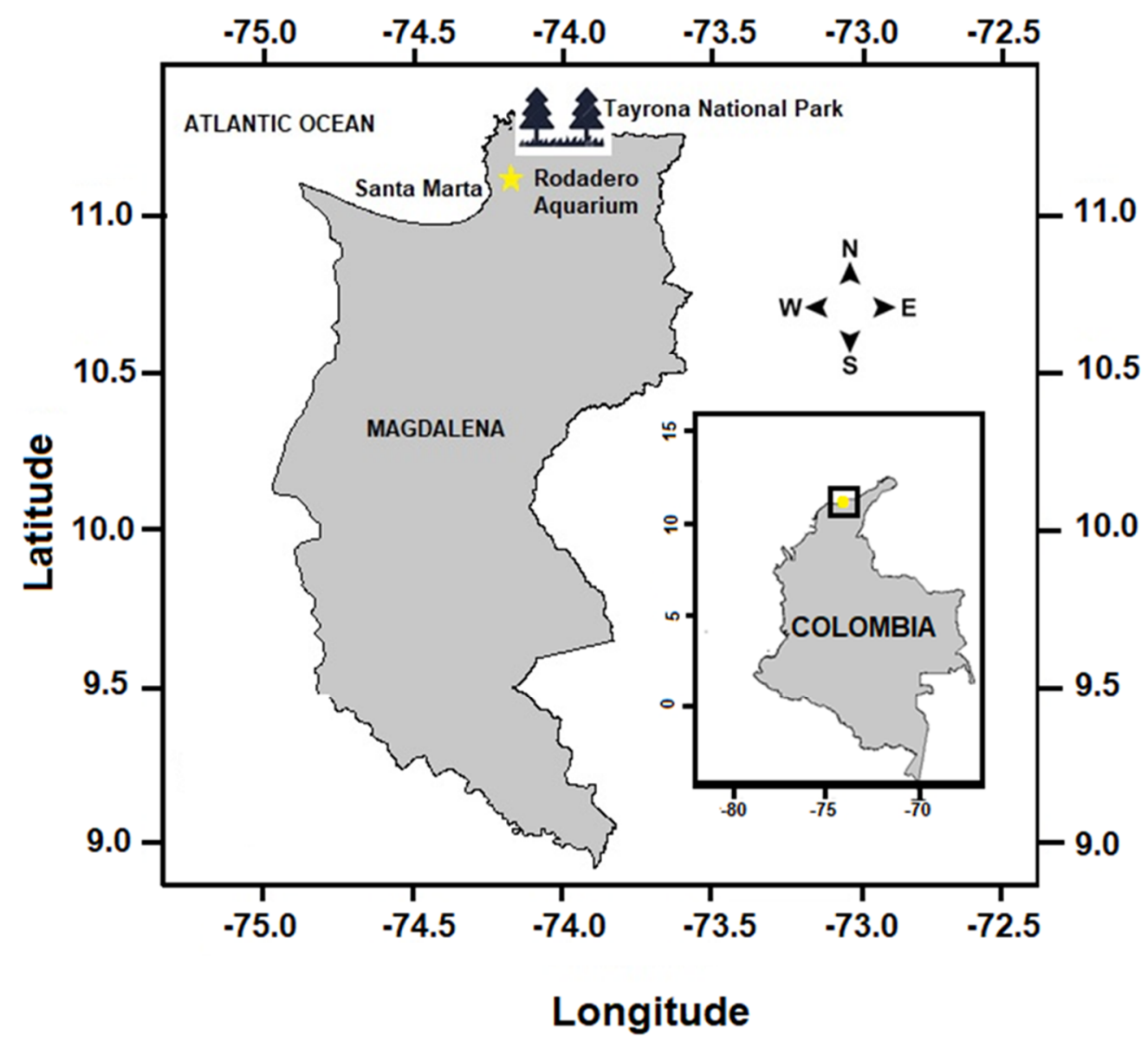

Figure 2. Location of El Rodadero Aquarium $\left(11^{\circ} 13^{\prime} 01^{\prime \prime} \mathrm{N} 74^{\circ} 14^{\prime} 14^{\prime \prime} \mathrm{W}\right)$, Santa Marta (Colombia), site for peripheral blood sampling site of the five individuals of loggerhead sea turtles. 


\subsection{Experimental Procedures}

\subsubsection{Isolation and Pre-Adaptation of Loggerhead Sea Turtles Erythrocytes}

All of the experiments were carried out in the laboratory of genetics and molecular biology of the Jorge Tadeo Lozano University. The RBCs of peripheral blood were isolated by centrifugation at $1500 \mathrm{rpm}$ for $2 \mathrm{~min}$ at $4{ }^{\circ} \mathrm{C}$. Plasma and buffy coat were removed. The RBCs packed in pellet were washed five times with phosphate buffered saline (PBS, $0.9 \% \mathrm{NaCl}$ in $10 \mathrm{mM}$ sodium phosphate buffer, $\mathrm{pH} 7.4)$ and suspended to prepare a $\%(\mathrm{v} / \mathrm{v})$ cell suspension in Minimum Essential Medium (MEM) (Gibco, Grand Island, NY, USA), supplemented with sodium carbonate, 13\% fetal bovine serum (FBS), and $1 \%$ antibiotics and antimycotics $(100 \mathrm{mg} / \mathrm{L}$ penicillin, $10 \mathrm{mg} / \mathrm{L}$ streptomycin) (MEM-S). In this culture medium, the RBCs were pre-adapted for $96 \mathrm{~h}$, incubated at $30^{\circ} \mathrm{C}$, and then used in the following bioassays.

\subsubsection{Determination of $\mathrm{LC}_{50}$ of Loggerhead Sea Turtles Erythrocytes}

Solutions of methylmercury (II) chloride $\mathrm{CH}_{3} \mathrm{HgCl}$ (Sigma-Aldrich, St. Louis, MO, USA) were prepared in PBS buffer at concentrations of $0.5,0.7,1,5,10,20,50$ y $100 \mathrm{mg} \mathrm{L}^{-1}$ to determine the $\mathrm{LC}_{50}$. An experimental unit was used for each concentration, plus an additional control group, each having three replicates. Each replica was served in $1.5 \mathrm{~mL}$ Eppendorf tubes containing $2.6 \times 10^{6} \mathrm{RBCs} / \mathrm{mL}$ dissolved in $180 \mu \mathrm{L}$ of MEM-S and $5 \mu \mathrm{L}$ of the appropriate MeHg solution. The cells were incubated at $30^{\circ} \mathrm{C}$ for $96 \mathrm{~h}$. Distilled water was added to the control group and the bioassay was repeated three times. At $96 \mathrm{~h}$, aliquots of $10 \mu \mathrm{L}$ of RBCs were mixed with $10 \mu \mathrm{L}$ of trypan blue solution (Sigma-Aldrich; Merck $\mathrm{KGaA}$ ). Living and dead cells were counted in a Neubauer counting chamber (Zeiss, Oberkochen, Germany) while using the Leica DM750 microscope (Leica Microsystems, Heerbrugg, Switzerland) with 40× magnification. $\mathrm{LC}_{50}$ was calculated through a Probit analysis [39] using the "MASS" package [40] that was included within the free RWizard software [41].

\subsubsection{Determination of Cell Viability of Loggerhead Sea Turtles RBCs}

Cell viability was evaluated at 0,1 , and $5 \mathrm{mg} \mathrm{L}^{-1}$ of $\mathrm{MeHg}$. These doses were selected based on the results of the $\mathrm{LC}_{50}$ test, which were also supported by previously published results [42]. The cell viability test was performed in triplicate, then, $2.6 \times 10^{6} \mathrm{RBCs} / \mathrm{mL}$ dissolved in $180 \mu \mathrm{L}$ of MEM-S and $5 \mu \mathrm{L}$ of the appropriate $\mathrm{MeHg}$ were incubated at $30^{\circ} \mathrm{C}$ for 6 and $12 \mathrm{~h}$ of exposure. Subsequently, $10 \mu \mathrm{L}$ of $0.4 \%$ (v/v) trypan blue solution (Sigma-Aldrich; Merck KGaA) and $10 \mu \mathrm{L}$ of RBCs suspension subjected to each of the $\mathrm{MeHg}$ concentrations were mixed in a polypropylene microtube and was incubated for $5 \mathrm{~min}$ at room temperature. $10 \mu \mathrm{L}$ of the Trypan blue/RBC cell mixture were then placed on a Neubauer counting chamber (Zeiss, Oberkochen, Germany) and, subsequently, stained (non-viable) and unstained cells (viable) were counted while using a $40 \times$ magnification microscope (Leica DM750 microscope, Leica Microsystems, Heerbrugg, Switzerland).

\subsection{Oxidative Stress of Loggerhead Sea Turtles Erythrocytes}

SOD and GST, $2 \times 10^{6} \mathrm{RBC} / \mathrm{mL}$ of loggerhead turtles exposed and not exposed to $\mathrm{MeHg}(0,1$ and $5 \mathrm{mg} \mathrm{L}^{-1}$ ) were used to assess oxidative stress markers. These were lysed with four volumes of ice-cold HPLC, and then centrifugated at $10,000 \mathrm{~g}$ for $15 \mathrm{~min}$ at $4{ }^{\circ} \mathrm{C}$. The supernatant (RBCs lysate) was collected for assaying and stored at $-80^{\circ} \mathrm{C}$. For the MDA assay, $2 \times 10^{7} \mathrm{RBCs} / \mathrm{mL}$ of loggerhead turtles exposed and not exposed to $\mathrm{MeHg}\left(0,1\right.$, and $\left.5 \mathrm{mg} \mathrm{L}^{-1}\right)$ were used. The samples were centrifugated at $2500 \mathrm{rpm}$ for $5 \mathrm{~min}$ at $4{ }^{\circ} \mathrm{C}$, and then resuspended in $1 \mathrm{~mL}$ of MEM. RBCs were collected and stored at $-80^{\circ} \mathrm{C}$ until use.

The activity of Superoxide Dismutase (SOD) and Glutathione S-Transferases (GST), and the levels of Malonaldehyde (MDA) were determined in RBCs lysate using commercial kits (Superoxide Dismutase Assay Kit [Item No. 706002], Glutathione S-Transferase Assay Kit [Item No. 703302], 
and TBARS assay kit [Item No. 10009055], Cayman Chemical Co, Ann Arbor, MI, USA), following the manufacturer's protocol for each Kit.

The Superoxide Dismutase (SOD) activity measuring kit is based on a method in which xanthine and xanthine oxidase react with tetezolium salt (2-(-4-iodophenyl)-3-(4-nitrophenol)-5-phenyl tetrazolium chloride), generating superoxide radicals, which then react and form formazan red. The SOD activity was then measured by the degree of inhibition of this reaction. In a 96-well microplate, $10 \mu \mathrm{L}$ of the Standard SOD enzyme (included in the kit, in AG wells) were served. In the rest of the microplate, $10 \mu \mathrm{L}$ of previously exposed and unexposed lysed $\mathrm{RBCs}\left(0,1\right.$, and $5 \mathrm{mg} \mathrm{L}^{-1}$ of $\left.\mathrm{MeHg}\right)$ were served (in triplicate), then, $200 \mu \mathrm{L}$ of the diluted radical detector were added to all wells. To start the reaction, $20 \mu \mathrm{L}$ of diluted xanthine oxidase were added to all wells, both standard and samples. Xanthine oxidase enzyme was not added for the control and the recorded readings were used to make the absorbance correction once the measurements were made. The plate was shaken for $30 \mathrm{~min}$ at room temperature and then the absorbance at $440-460 \mathrm{~nm}$ was measured in a plate reader (Elisa reader Expert 96 ASYS Hitech, Eugendorf, Austria). The average absorbance of each standard and sample was calculated and then corrected, subtracting the absorbance recorded in the control. The linearized rate (LR) of all standards was calculated, first dividing the absorbance of standard A by itself and then that of the other BG standards dividing the value recorded in $\mathrm{A}$, by those that were recorded in each of the BG standards. This means LR for Std A = Abs Std A/Abs Std A; LR for Std B = Abs Std A/Abs Std $B$, and so on. The linear standard SOD rate (LR) was plotted against the final SOD activity (U/mL).

The SOD activity of the samples was calculated while using the equation that was obtained from the linear regression of the standard curve, substituting the linearized rate (LR) for each sample. A unit of SOD is defined as the amount of enzyme that is required to exhibit a $50 \%$ dismutation of the superoxide radical. SOD activity is standardized while using the coupled cytochrome $\mathrm{c}$ and xanthine oxidase assay. The results were presented in international units per milliliter $(\mathrm{U} / \mathrm{mL})$.

$$
O D\left(\frac{U}{m L}\right)=\left[\left(\text { sample } L R-y-\frac{\text { intercept }}{\text { slope }}\right) \times\left(\frac{0.23 m L}{0.01 m L}\right)\right] \times \text { Sample dilution }
$$

The GST enzyme was quantified in triplicate in RBCs lysate. $150 \mu \mathrm{L}$ of assay buffer, $20 \mu \mathrm{L}$ of glutathione, and $20 \mu \mathrm{L}$ of each of the previously exposed and unexposed lysed RBC samples $(0,1$, and $5 \mathrm{mg} \mathrm{L}^{-1} \mathrm{MeHg}$ ) were served in a 96-well microplate. As a negative control, $170 \mu \mathrm{L}$ of test buffer and $20 \mu \mathrm{L}$ of glutathione were used, and as a positive control, $150 \mu \mathrm{L}$ of test buffer, $20 \mu \mathrm{L}$ of glutathione, and $20 \mu \mathrm{L}$ of reconstituted GST. The reaction was started by adding $10 \mu \mathrm{L}$ of CDNB (included in the kit) to all wells and gently shaking the microplate. GST activity was read at $340 \mathrm{~nm}$ on a plate reader (Elisa reader Expert 96 ASYS Hitech, Eugendorf, Austria). The addition of the GST produced an increase of between 0.012 and $0.064 / \mathrm{min}$. The change in absorbance over time was calculated while using the following equation, (where A represents the absorbance at $340 \mathrm{~nm}$ ):

$$
\frac{\Delta A}{\min }=\frac{A(\text { Time } 2)-A(\text { Time } 1)}{\text { Time } 2(\text { min })-\text { Time } 1(\min )}
$$

GST activity was calculated using the following formula:

$$
\text { ST Activity }=\frac{\frac{\Delta A}{m i n}}{\frac{1}{0.00503 \mu M}} \times\left(\frac{0.2 m L}{0.02 m L}\right) \times \text { Sample dilution }=\frac{\frac{n m o l}{m i n}}{m L}
$$

The reaction rate can be determined while using the CDNB extinction coefficient of $0.00503 \mu \mathrm{M}^{-1}$. One unit of the enzyme will be conjugated to $1.0 \mathrm{mMol}$ of CDNB with reduced glutathione for one minute at $25^{\circ} \mathrm{C}$. The actual extinction coefficient para CDNB at $340 \mathrm{~nm}$ is $0.0096 \mu \mathrm{M}^{-1} \mathrm{~cm}^{-1}$ [43]. This value has been adjusted for the pathlenght of the solution of the well $(0.524 \mathrm{~cm})$. 
The MDA concentration in RBCs was quantified in duplicate using the RBCs collected previously and stored at $-80{ }^{\circ} \mathrm{C}$. RBCs were sonicated at $36 \%$ amplitude with three pulses of $20 \mathrm{~s}$ each, using a sonicator (Sonics Vibra Cell, 750 W, Newtown, CT 06470, USA). RBCs thatwere resuspended in MEM and malonaldehyde standards (100 $\mu \mathrm{L}$ MDA, included in the kit) were mixed in $5 \mathrm{~mL}$ falcon tubes with $100 \mu \mathrm{L}$ of SDS and $4 \mathrm{~mL}$ of the color reagent (included in the kit). All tubes were placed in a serological bath for $1 \mathrm{~h}$ at $100{ }^{\circ} \mathrm{C}$, then incubated on ice for $10 \mathrm{~min}$ to stop the reaction. They were then spun at $1600 \mathrm{rpm}$ for $10 \mathrm{~min}$ at $4{ }^{\circ} \mathrm{C} .160 \mu \mathrm{L}$ aliquots of each of the treatments and standards were added to a 96-well microplate. MDA measurement was performed spectrophotometrically at $530 \mathrm{~nm}$, on a plate reader (Elisa Expert 96 reader (ASYS Hitech, Eugendorf, Austria). The measurement of MDA concentration was reported in $\mu \mathrm{M}$.

Absorbances in all cases were corrected, as follows: (1) the average absorbance of each sample and the standard sample was calculated, (2) the absorbance value was subtracted from the standard A $(0 \mu \mathrm{M})$ of itself and the other values (both standards and samples, and the corrected absorbance were found), (3) the corrected absorbance of the standard samples was graphed as a function of the MDA concentration, and (4) the MDA values for each sample of the standard curve were calculated using the equation:

$$
\operatorname{MDA}(\mu \mathrm{M})=\frac{(\text { corrected absorbance })-(y-\text { intercept })}{\text { Slope of the line }}
$$

\subsection{Data Analysis}

Statistical analyzes for biochemical biomarker data (SOD, MDA, and GST concentration) in controls and treatments were subjected to a normality test and the homogeneity variance test using the Shapiro Wilk, Kolmogorov-Smirnov, and Levene tests, respectively. Significant differences between treatments and control were determined by an ANOVA test and then by multiple comparisons between treatments using the Tukey test. The sample size did not allow for stipulating significant differences between the treatments. The correlation coefficients of Pearson, Spearman, and Kendal were calculated to determine whether there is a correlation between the concentrations of $\mathrm{MeHg}$ to which the erythrocytes were exposed and the observed levels of GST, SOD and MDA at 6 and $12 \mathrm{~h}$ of exposure. To carry out the analyzes and figures, the R program was used [44] with RWizard software [41].

\section{Results}

\subsection{Blood Count and Health Status of Loggerhead Turtles}

The sampled individuals' sex could not be determined because of their immature development state. They had an average weight of $2.78 \pm 0.29 \mathrm{~kg}$, an average straight carapace length (SCL) of $29.4 \pm 2.41 \mathrm{~cm}$, and an average curve carapace length (CCL) of $26.2 \pm 2.71 \mathrm{~cm}$ (Table 1). With these SCL, turtles are considered to be pre-juveniles $[36,37]$. The blood count was conducted prior to the $\mathrm{MeHg}$ bioassay in order to determine the health status of the turtles. All of the specimens presented an apparently good state of health that was corroborated by all of the obtained blood parameters (Table 2). The percentages of lymphocyte count, mean corpuscular volume, and the percentage of lymphocytes, eosinophils, and monocytes were similar to those previously reported [34]. The variations in concentration of the different parameters were within the accepted levels $[34,35]$. Nonetheless, the blood parameters between the different species of sea turtles, and between free-living or captive individuals of the same species are different and, in some cases, highly variable, depending on their geographical distribution, $[4,45,46]$, as numerous additional intrinsic and extrinsic factors can impact blood composition. 
Table 1. Body size of the $\mathrm{f}$ specimens of loggerhead sea turtles sampled for erythrocytes, identification number, live weight, Straight Carapace Length (SCL), and Curved Cap Width (ACL).

\begin{tabular}{cccc}
\hline ID of Turtles & Weight $\mathbf{( K g )}$ & SCL $\mathbf{( c m})$ & ACL $(\mathbf{c m})$ \\
\hline UJTL-CC1 & 3.0 & 31 & 28 \\
UJTL-CC3 & 2.9 & 30 & 28 \\
UJTL-CC5 & 2.6 & 29 & 24 \\
UJTL-CC7 & 2.3 & 25 & 22 \\
UJTL-CC8 & 3.1 & 32 & 29 \\
\hline
\end{tabular}

Table 2. Blood parameters of captive loggerhead sea turtles from El Rodadero Aquarium, Santa Marta. $\mathrm{SD}=$ standard deviation $(\mathrm{n}=5)$. Reference values taken from Yang et al., and Rouselet et al. [47,48]. M.C.V.: medium corpuscular volume; H.C.M.: amount of hemoglobin per red blood cell; C.M.H.C.: mean corpuscular hemoglobin concentration.

\begin{tabular}{|c|c|c|c|c|c|c|}
\hline \multicolumn{7}{|c|}{ HEMOGRAM } \\
\hline Variable & Mean & SD & Min & Max & Reference & Unit \\
\hline ERYTHROCYTES & 1.42 & 0.13 & 1.21 & 1.61 & $1.60-70.0$ & $10^{5}$ Cells $/ \mu \mathrm{L}$ \\
\hline HEMOGLOBIN & 3 & 0.59 & 2.1 & 3.7 & $3.9-9.5$ & $\mathrm{~g} / \mathrm{L}$ \\
\hline HEMATOCRIT & 6.98 & 1.20 & 5 & 8.4 & $9.5-36.0$ & $(\%)$ \\
\hline M.V.C & 488.5 & 49.97 & 413.2 & 560 & $257.1-1188$ & Femtoliters \\
\hline H.C.M. & 210.2 & 30.37 & 174 & 247 & $157.7-216.3$ & Picograms \\
\hline C.M.H.C. & 43.2 & 5.91 & 37 & 54 & $24.1-32.4$ & $(\mathrm{~g} \%)$ \\
\hline $\begin{array}{l}\text { PLASMATIC } \\
\text { PROTEIN }\end{array}$ & 9.74 & 1.23 & 8.5 & 12 & $1.2-5.0$ & $\mathrm{~g} / \mathrm{L}$ \\
\hline ALBUMIN & 6.72 & 0.89 & 5.4 & 8 & $0.8-2.2$ & $\mathrm{~g} / \mathrm{L}$ \\
\hline GLOBULINS & 3.02 & 1.44 & 1.8 & 5.6 & $0.2-3.3$ & $\mathrm{~g} / \mathrm{L}$ \\
\hline THROMBOCYTES & 24 & 12.65 & 3 & 42 & & Cells/ $/ \mu \mathrm{L}$ \\
\hline LEUCOCYTES & 1.83 & 0.14 & 1.59 & 1.99 & $1.760-23.60$ & $10^{3}$ Cells $/ \mu \mathrm{L}$ \\
\hline HETEROPHILE & 42 & 2.37 & 38 & 45 & $14.8-91.6$ & $(\%)$ \\
\hline BASOPHILS & 3.6 & 0.8 & 3 & 5 & $0-16$ & $(\%)$ \\
\hline EOSINOPHILS & 3 & 1.09 & 2 & 5 & $0-13.7$ & $(\%)$ \\
\hline LYMPHOCYTES & 45 & 3.03 & 41 & 49 & $17.2-90$ & $(\%)$ \\
\hline MONOCYTES & 3.4 & 1.85 & 1 & 6 & $0-16.1$ & $(\%)$ \\
\hline AZUROPHILES & 3 & 1.41 & 1 & 5 & $1-8$ & $(\%)$ \\
\hline \multicolumn{7}{|c|}{ ABSOLUTE PARAMETERS } \\
\hline LYMPHOCYTES & 820 & 50 & 747 & 892 & $429.8-11034.3$ & Cells/ $\mu \mathrm{L}$ \\
\hline HETEROPHILE & 790 & 60 & 692 & 856 & $1308.1-8400.9$ & Cells/ $\mu \mathrm{L}$ \\
\hline EOSINOPHILS & 50 & 20 & 32 & 98 & $13.6-2580.2$ & Cells/ $\mu \mathrm{L}$ \\
\hline MONOCYTES & 60 & 40 & 18 & 117 & $7.2-2796.6$ & Cells/ $\mu \mathrm{L}$ \\
\hline BASOPHILS & 60 & 20 & 0.048 & 0.1 & $0.064-0.928$ & $10^{3}$ Cells $/ \mu \mathrm{L}$ \\
\hline AZUROPHILES & 60 & 30 & 15.9 & 99.5 & $78.4-729.9$ & Cells $/ \mu \mathrm{L}$ \\
\hline
\end{tabular}

\subsection{Quantification of $\mathrm{Hg}$ in Erythrocytes of Loggerhead Turtles}

The concentration of $\mathrm{Hg}$ in seawater samples and in $100 \mu \mathrm{L}$ samples of RBCs was determined by atomic adsorption (see details above). The background $\mathrm{Hg}$-T concentrations in control seawater was $0.0032 \pm 0.001 \mathrm{mg} \mathrm{L}^{-1}(0.00323 \mathrm{ppm})$, whereas the background $\mathrm{Hg}-\mathrm{T}$ concentrations in RBCs (before the bioassay) were $0.031 \pm 0.011 \mathrm{mg} \mathrm{L}^{-1}$ on average. After the bioassay, at $12 \mathrm{~h}$, the RBCs exposed to concentration of $1 \mathrm{mg} \mathrm{L}^{-1}(1 \mathrm{ppm})$ had an average $\mathrm{Hg}$-T concentration of $0.31 \pm 0.10 \mathrm{mg} \mathrm{L}^{-1}$ and those exposed to $5 \mathrm{mg} \mathrm{L}^{-1}$ (5 ppm) contained $2.18 \pm 0.77 \mathrm{mg} \mathrm{L}^{-1}$. These results demonstrate the high affinity of RBCs for $\mathrm{Hg}$ accumulation, due to their great capacity to retain it in cell membranes [49]. 


\subsection{Lethal Concentration $\left(L_{50}\right)$ and Cell Viability of Erythrocytes of Loggerhead Turtles}

Loggerhead RBCs that were exposed to 50 and $100 \mathrm{mg} \mathrm{L}^{-1}$ of $\mathrm{MeHg}$ for $96 \mathrm{~h}$ had $100 \%$ cell mortality (Figure 3). For all other exposure concentrations, cell viability ranged from $90 \%$ to $20 \%$. From these data, the $\mathrm{LC}_{50}$ was obtained with a value of $8.32 \mathrm{mg} \mathrm{L}^{-1}(8.32 \mathrm{ppm})$. Based on these results, it was decided to perform the bioassays for the determination of oxidative stress in the RBCs of loggerhead turtles at 0,1 , and $5 \mathrm{mg} \mathrm{L}^{-1}$ of $\mathrm{MeHg}$, and for incubation durations of 6 and $12 \mathrm{~h}$.

In the bioassay of cell viability, the RBCs that were exposed to 0,1 , and $5 \mathrm{mg} \mathrm{L}^{-1}$ of MeHg for $12 \mathrm{~h}$ showed $100 \%$ viability.

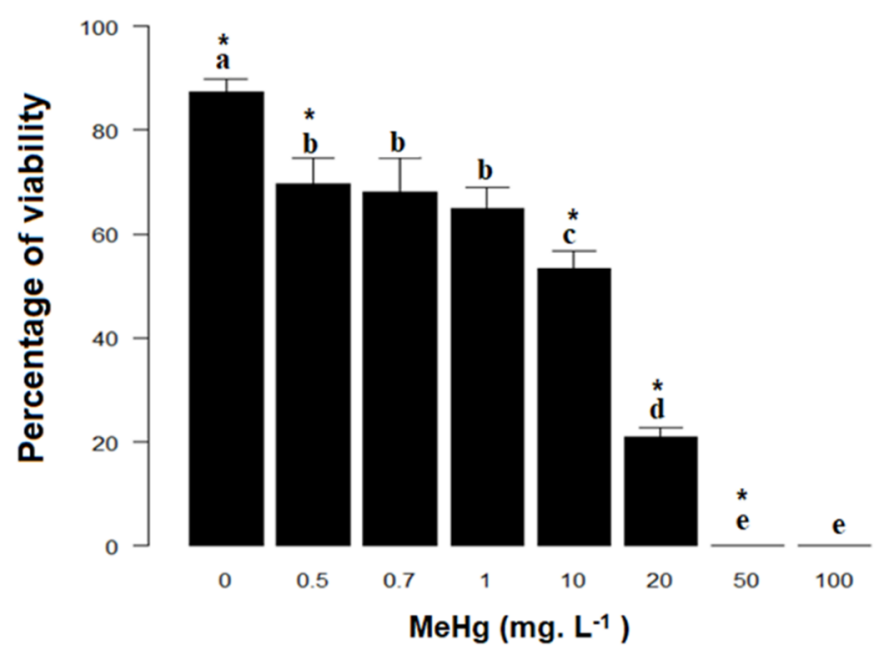

Figure 3. Cell viability of erythrocytes of loggerhead sea turtle against different concentrations of methylmercury, used for calculating lethal concentration $\left(\mathrm{LC}_{50}\right)$. Error bars indicate mean and standard deviation. Treatments with significant differences (ANOVA, $p<0.05$ ) indicated by asterisk $(*$ ). Treatments with non-significant differences indicated by same letter $(a, b, c, d, e)$.

\subsection{Bioassay and Oxidative Stress}

The SOD activity presented variations in each of the different treatments. At $6 \mathrm{~h}$, the SOD activity of RBCs exposed to $1 \mathrm{mg} \mathrm{L}^{-1}$ of MeHg was slightly more than double that in controls (1.56 $\pm 0.58 \mathrm{vs}$. $0.72 \pm 0.24 \mathrm{U} / \mathrm{mL}$ of RBCs), and slightly greater than at $5 \mathrm{mg} \mathrm{L}^{-1} \mathrm{MeHg}(1.20 \pm 0.52 \mathrm{U} / \mathrm{mL})$, which, in turn, was higher than in the control, demonstrating that RBCs at 1 and $5 \mathrm{mg} \mathrm{L}^{-1}$ of MeHg experienced oxidative stress (Figure 4A). After $12 \mathrm{~h}$ of exposure, SOD activity was higher in RBCs that were exposed to $5 \mathrm{mg} \mathrm{L}^{-1} \mathrm{MeHg}(1.39 \pm 0.45 \mathrm{U} / \mathrm{mL})$ than in controls $(0.82 \pm 0.24 \mathrm{U} / \mathrm{mL})$ and those RBCs exposed to $1 \mathrm{mg} \mathrm{L}^{-1}$ of MeHg $(1.08 \pm 0.25 \mathrm{U} / \mathrm{mL})$, again indicating oxidative stress. There were no statistically significant differences between RBCs' SOD activity for the two MeHg exposure concentrations (1 and $5 \mathrm{mg} \mathrm{L}^{-1}$ ) for either of the two exposure durations ( 6 and $12 \mathrm{~h}$ ), no correlation between the SOD activity and $\mathrm{MeHg}$ concentration to which the RBCs were exposed after $6 \mathrm{~h}$ of exposure (in all cases $p>0.05$ ).

The glutathione transferase activity of loggerhead turtle RBCs at 6 and $12 \mathrm{~h}$ of exposure showed variations in cells that were exposed to 1 and $5 \mathrm{mg} \mathrm{L}^{-1}$ of MeHg with respect to the control. At $6 \mathrm{~h}$, the GST activity was higher for the 1 and $5 \mathrm{mg} \mathrm{L}^{-1} \mathrm{MeHg}$ treatments as compared to the control $(12.72 \pm 5.41$ and $11.93 \pm 9.54 \mathrm{vs.} 6.76 \pm 4.93 \mathrm{nmol} / \mathrm{min} / \mathrm{mL}$ of RBCs, respectively, demonstrating high response to the concentration and exposure time to $\mathrm{MeHg}$. However, after $12 \mathrm{~h}$ of $\mathrm{MeHg}$ exposure, the GST activity was lower in RBCs exposed to $5 \mathrm{mg} \mathrm{L}^{-1} \mathrm{MeHg}$ when compared to those exposed to $1 \mathrm{mg} \mathrm{L}^{-1} \mathrm{MeHg}$ and to the control $(5.96 \pm 6.36$ vs. $9.54 \pm 8.91$ and $6.92 \pm 5.16 \mathrm{nmol} / \mathrm{min} / \mathrm{mL}$ of RBCs), respectively. Nevertheless, the observed differences between $\mathrm{MeHg}$ treatments and the control were not statistically significant for any exposure concentrations or time point (in all cases $p>0.05$ ) (Figure 4B). 

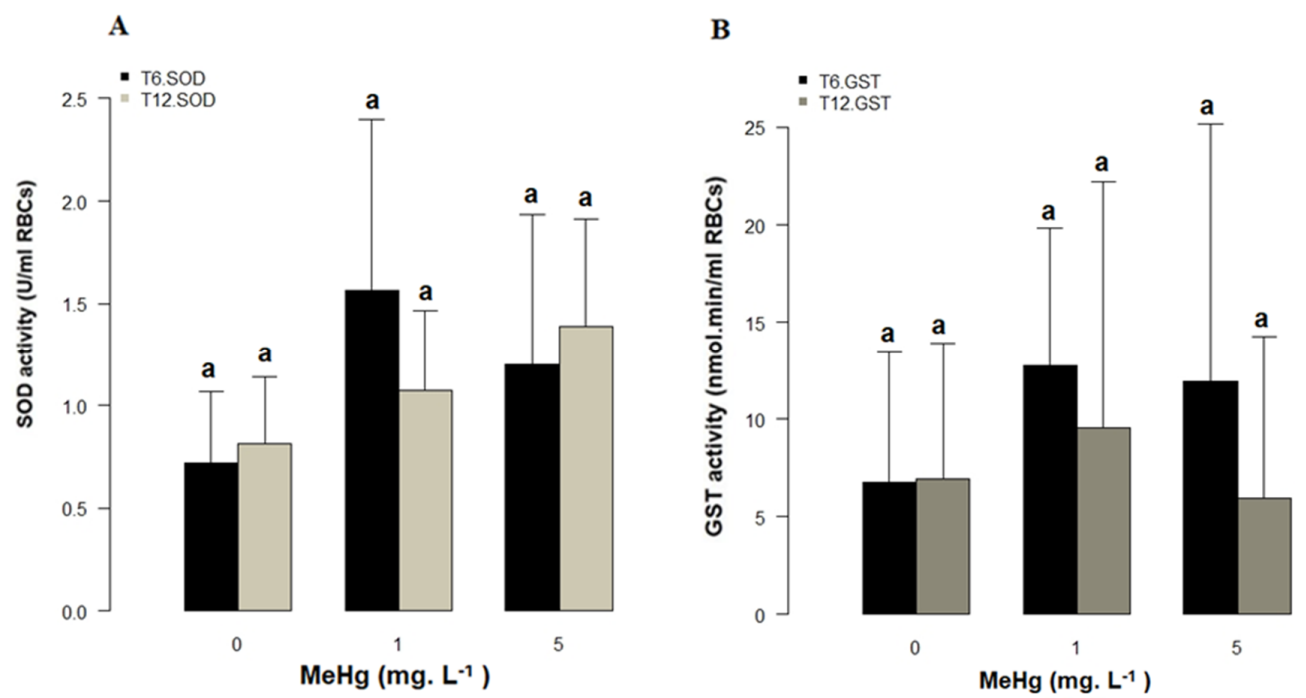

Figure 4. Activities of (A) Superoxide dismutase (SOD) and (B) glutathione S-transferase (GST) in erythrocytes of loggerhead turtles exposed to methylmercury (MeHg) at 0,1 and $5 \mathrm{mg} \mathrm{L}^{-1}$ for 6 and $12 \mathrm{~h}$ (mean \pm standard error of the mean, $(n=5)$. Differences between treatments were statistically non-significant in all cases $(p>0.05)$.

The malondialdehyde (MDA) levels increased with respect to the control with increasing $\mathrm{MeHg}$ concentration and exposure time. After $6 \mathrm{~h}$, the MDA concentrations were $38.31 \pm 20.92$ and $46.65 \pm 13.42 \mu \mathrm{M}$ for 1 and $5 \mathrm{mg} \mathrm{L}^{-1} \mathrm{MeHg}$, respectively, when compared to $27.58 \pm 0.42 \mu \mathrm{M}$ in the controls. After $12 \mathrm{~h}$, the MDA concentrations increased to $49.15 \pm 15.75$ and $56.38 \pm 13.97 \mu \mathrm{M}$ of MDA for 1 and $5 \mathrm{mgL}^{-1} \mathrm{MeHg}$, respectively, whereas MDA in controls remained virtually unchanged $(28.91 \pm 9.35 \mu \mathrm{M}$, Figure 5). While the observed differences between treatments were not considered to be statistically significant (ANOVA, $p>0.05$ ), a positive correlation was observed between the MDA concentrations and $\mathrm{MeHg}$ concentrations after $12 \mathrm{~h}$ of exposure time ( $\mathrm{r}$ Spearman $=0.56, p<0.05$, Figure 6). This result is preliminary; therefore, it is necessary to carry out evaluations with a larger sample to improve the statistical significance of this analysis and verify this possible correlation.

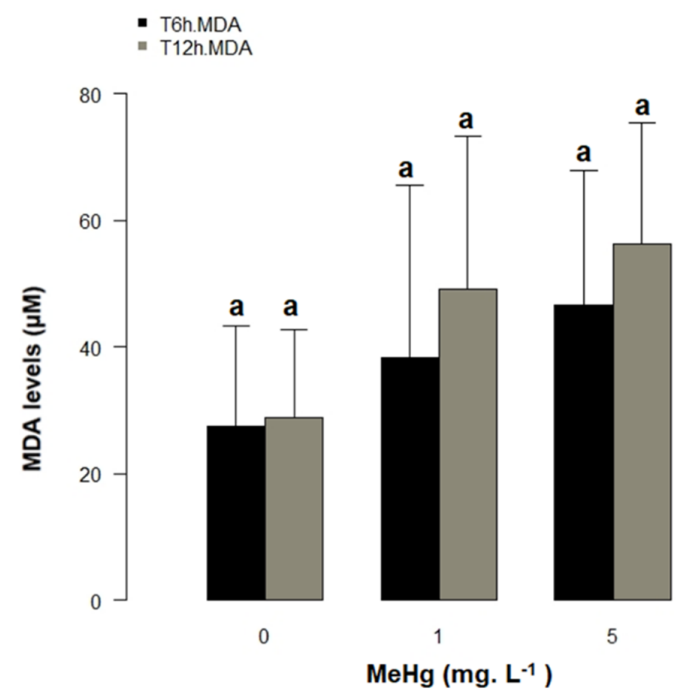

Figure 5. Malondialdehyde (MDA) levels in control (untreated erythrocytes) and in erythrocytes exposed to $\mathrm{MeHg}$ at 1 and $5 \mathrm{mg} \mathrm{L}^{-1}$ for 6 and $12 \mathrm{~h}$ (mean \pm standard error of the mean, $\mathrm{n}=5$ ). Differences between treatments were non-significant in all cases $(p>0.05)$. 


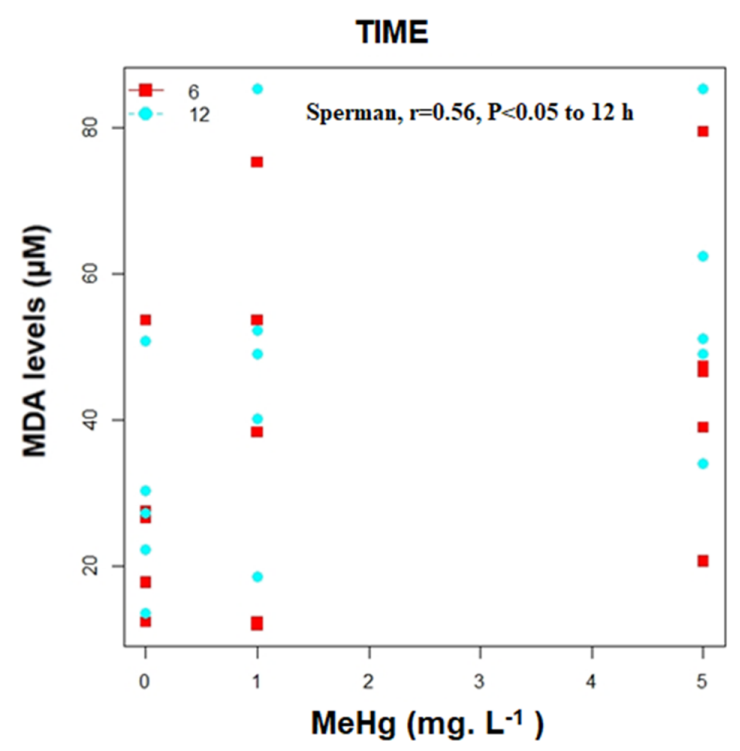

Figure 6. Spearman's correlation between the variables MeHg concentration, exposure time and MDA levels.

\section{Discussion}

The present study is the first report on oxidative stress of RBCs of captive loggerhead turtles (Caretta caretta) that were exposed to methylmercury in bioassays. RBCs of sea turtles have not been used to perform in vitro bioassays until today. This study showed RBCs to be a sensitive, simple, and inexpensive model for performing bioassays for ecotoxicological evaluation of heavy metals, such as mercury and, potentially, other environmental pollutants. Furthermore, SOD, GST, and MDA were sensitive biomarkers of environmental pollution and oxidative stress in loggerhead turtles.

The blood count was conducted prior to the MeHg bioassay, in order to show the health status of the turtles. Plasma and hematological biochemistry analytes vary significantly between loggerhead turtle populations in the wild, due to environmental factors, temperature, type of diet, sex, size, $\mathrm{pH}$, salinity, water quality, population density, development stage, maturity, weight, and season [50,51]. Additionally, the hematological response to man-made influences must be taken in consideration when reviewing previously published data. For these reasons, it is important to establish population-specific reference information [52]. In this study, all of the specimens presented an apparently good health showed by the blood parameters obtained (Table 2). The percentages of all white blood cells were within the previously described ranges for loggerhead turtles (Figure 7, [47]). Additionally, mean corpuscular volume, albumin, and plasma protein were similar to those reported previously $[47,48,51-53]$. The variations in concentration of the different parameters were within the accepted levels [53,54]. A simple analysis that is presented in Figure 7 shows that the percentages of white cells: heterophile, eosinophils, limphocythes, monocytes, and azurophiles are within the reference ranges [47] that are present in loggerhead turtles with an apparent good health. However, as we have seen, the size and weight of turtles are important variables that produce large variations in the concentrations of the different hematological analytes. In the study that was carried out by Yang et al. (2019) [47], the 191 analyzed individuals are 2.5 times larger than the individuals in our study according to the SCL range (54.8-100.8 cm vs. $25-32 \mathrm{~cm}$ ). For this reason, the percentages of the heterophile and limphocythes in this study are approximately half of the maximum values (91.6\% and $90 \%$, respectively). In the same way, the eosinophils, monocytes, and azurophiles found are four, five, and three times under the maximum value $(13.7 \%, 16.1 \%$, and $8 \%$, respectively). All of the cell types exceed the minimum range to present them within the normal ranges. These differences are apparently a result of the weight and size of the turtles, but, as described above, it might be due to other variables, such as captivity, feeding, and/or stress [50,51]. 


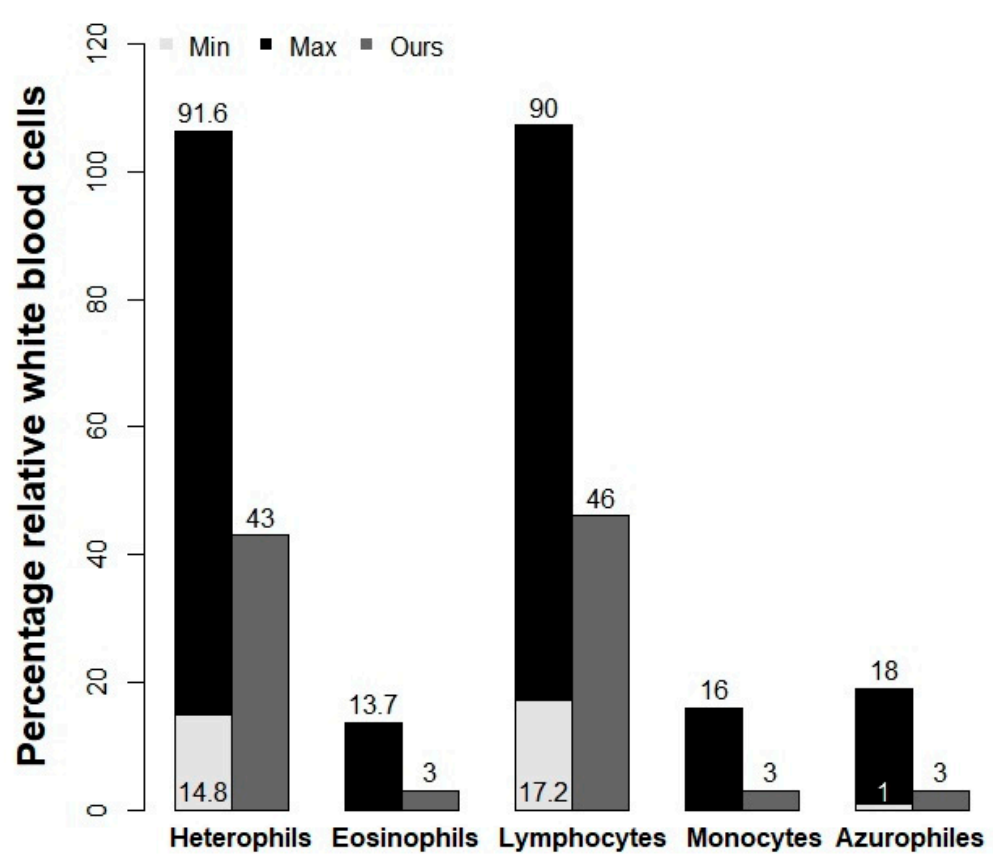

White blood cells

Figure 7. Comparison between the percentages relative to white cells in the blood counts for the loggerhead turtles (Caretta caretta) (ours) and the minimum and maximum ranges published by Yang et al. (2019).

This study used captive loggerhead turtles. For this reason, the background $\mathrm{Hg}-\mathrm{T}$ in water and in turtle RBCs were determined prior to bioassays $\left(0.0032 \pm 0.001 \mathrm{mg} \mathrm{L}^{-1}\right.$ and $0.031 \pm 0.011 \mathrm{mg} \mathrm{L}^{-1}$, respectively). The 10-fold concentration of baseline $\mathrm{Hg}$ - $\mathrm{T}$ in $\mathrm{RBC}$ s demonstrates how feeding is an important factor for the bioaccumulation and biomagnification of this metal. The diet of loggerhead turtles in their natural habitat is composed of cnidarians, gastropods, copepods, and other crustaceans, polychaetes, cephalopods, fish, algae, plant remains, fish eggs, and hydrozoans [55]. In this study, captive donor loggerhead turtles from Santa Martha Aquarium were fed with fish of species as machuelo (Opisthonema oglinum), macabí (Elops saurus) and picuda (Sphyraena ensis). It is presumed that fish diet had $\mathrm{Hg}$ concentrations like those that were previously reported for machuelo (Opisthonema oglinum) $\left(0.11 \mu \mathrm{g} \mathrm{L}^{-1}\right)$ [56].

In the present study, the average total mercury (Hg-T in RBCs) concentration of $0.031 \pm 0.011 \mathrm{mg} \mathrm{L}^{-1}$ was obtained prior to bioassay and, after $12 \mathrm{~h}$ of bioassay with erythrocytes at $1 \mathrm{mg} \mathrm{L}^{-1} \mathrm{MeHg}$, the concentration of $\mathrm{Hg}$-T increased approximately 10 times $\left(0.309 \pm 0.10 \mathrm{mg} \mathrm{L}^{-1}\right)$. At $5 \mathrm{mg} \mathrm{L}^{-1}$ of $\mathrm{MeHg}$, the $\mathrm{Hg}$ - $\mathrm{T}$ concentrations increased to $2.183 \pm 0.77 \mathrm{mg} \mathrm{L}^{-1}$, being 70 times higher than controls and seven times higher than RBCs that were subjected to $1 \mathrm{mg} \mathrm{L}^{-1}$ of MeHg.

Various studies have shown that the different dissolved forms of mercury have a high affinity for the sulfhydryl groups present in the cells, and that in their methylated state it has an affinity of over 90\% for human RBCs, where it adheres in less than an hour [22,57,58]. Studies of RBCs of mammalian species have also shown that MeHg is evenly distributed between intra and extracellular hemoglobin $[59,60]$. In this study, these results demonstrate the high affinity of RBCs for $\mathrm{Hg}$ and their great capacity to retain it inside of the cell.

Moreover, the MeHg median lethal concentration $\left(\mathrm{LC}_{50}\right)$ of $\mathrm{RBC}$ s for loggerhead turtles exposed in vitro was determined in this study, eight $\mathrm{MeHg}$ doses ranging from $0.5-100 \mathrm{mg} \mathrm{L}^{-1}$, in addition to seawater controls. At the two highest concentrations, there was 100\% cell mortality (Figure 3). In the control group, mortality was $13 \%$ and it increased with the $\mathrm{MeHg}$ concentration. The $\mathrm{LC}_{50}$ for loggerhead turtle RBCs was $8.32 \mathrm{mg} \mathrm{L}^{-1}$ after $96 \mathrm{~h}$ of incubation. To date, there are no published studies 
on $\mathrm{LC}_{50}$ of $\mathrm{MeHg}$ on loggerhead sea turtle RBCs, so there are no literature values to compare these results with. Recently, the use of RBCs was reported in turtle studies of the red eared sliders species (Trachemys callirostris) to assess the genotoxic effect of environmental pollutants [61]. Cocci et al. [62] described the use of primary erythrocyte cell cultures as in vitro models for evaluating the effects of different endocrine disrupting chemicals. Finlayson et al. [55] established primary cell cultures from the intestine, heart, liver, ovary, and skin of green sea turtles (Chelonia mydas), and skin for loggerhead turtles and determined the mean effective concentration $\left(\mathrm{EC}_{50}\right)$ with an average for all cell types of $18,4 \mu \mathrm{M}$ for $\mathrm{Hg}^{+2}$, being skin tissue the most sensible. In this study, $\mathrm{LC}_{50}$ was found to be almost double this value $(33.05 \mu \mathrm{M})$. They found significant differences between the different cell types evaluated. In this study, other cell types, RBCs, were evaluated in loggerhead turtles, also showing great differences. The differences in response to $\mathrm{Hg}$ contamination between cells and between different species are appreciable [63-65]. Cytotoxicity is generally due to non-specific molecular and cellular effects [55]. Some pollutants, such as $\mathrm{Hg}$, have higher accumulation values in loggerhead turtles $[66,67]$. Loggerhead sea turtles' RBCs appear to have a higher sensitivity and affinity for Hg than skin cells and other tissues (as described above), which would produce the big difference between these two results. RBCs could represent a better in vitro model for toxicological studies than primary cell cultures according to this result, and due to the high sensitivity of the RBCs presented here. However, primary cell cultures can be used to specifically study the response of organs to environmental pollutants. Viability studies that were conducted in RBCs in marine fish species as Sparus aurata and Dicentrarchus labrax have reported $\mathrm{LC}_{50}$ of 5.25 and $7.25 \mathrm{mg} \mathrm{L}^{-1}$, respectively, in $\mathrm{RBC}$ s that were exposed to $\mathrm{MeHg}$ for $24 \mathrm{~h} \mathrm{[49].} \mathrm{This} \mathrm{result} \mathrm{is} \mathrm{similar} \mathrm{to} \mathrm{the} \mathrm{present} \mathrm{study,} \mathrm{although} \mathrm{the} \mathrm{exposure} \mathrm{times} \mathrm{are} \mathrm{different,} \mathrm{showing}$ that the RBCs of the turtles are more resistant. We found that loggerhead turtle RBCs can survive at $4{ }^{\circ} \mathrm{C}$ for about eight weeks when stored with plasma. The determination of the $\mathrm{LC}_{50}$ allowed for selecting the appropriate concentrations of $\mathrm{MeHg}$ to be used in the bioassay $\left(0,1\right.$, and $\left.5 \mathrm{mg} \mathrm{L}^{-1}\right)$, so that the majority of RBCs remained alive until the end of the bioassay, as corroborated by cell viability close to $100 \%$.

Studies on oxidative damage to wild animals from an ecological perspective have been conducted over the past 20 years [68], but knowledge on oxidative stress in sea turtles is scarce [1,55,69,70]. Further, the toxic level of $\mathrm{Hg}$ and others metals and their short- and long-term adverse effects are still unknown for sea turtles $[1,55,71]$.

RBCs have an antioxidant defense system that is composed of the enzymes superoxide dismutase (SOD), catalase (CAT), and glutathione peroxidase (GPx) and molecules, such as reduced glutathione (GSH), tierrodoxins, alpha tocopherol, beta carotene, and vitamin C [72]. The exposure of RBCs to methylmercury induces oxidative stress, which destabilizes the lipid bilayer of the cell membrane and causes morphological and physiological changes in the cell $[63,73]$. RBCs increase or decrease the expression levels of catalase, superoxide dismutase, and glutathione enzymes in order to counteract stress. These enzymes have been monitored in sea turtles in blood and liver tissues [74,75] to determine the correlation between the bioaccumulation of metals and oxidative stress and, in this way, understand the possible mechanisms that sea turtles use to balance themselves. There are no reports of in vitro bioassays of RBCs of sea turtles that were exposed to $\mathrm{MeHg}$ where oxidative stress is evaluated.

In this study, where loggerhead RBCs exposed in concentrations of $5 \mathrm{mg} \mathrm{L}^{-1}$ of $\mathrm{MeHg}$, cells presented lipid peroxidation and reduction in the enzymatic activity of SOD and GST after $6 \mathrm{~h}$ of exposure. It seems that high concentrations of $\mathrm{MeHg}$ inhibit the expression of enzymes and, therefore, their activity [76-78]. These results are similar to those that were reported by Berntssen et al. [76] in brain, liver, and kidney tissues of fish that were exposed to 5 and $10 \mathrm{mg} \mathrm{L}^{-1} \mathrm{MeHg}$. Greater susceptibility of brain tissue to oxidative stress was reported, which was represented by increased levels of lipid peroxidation (MDA) and ROS formation, and parallel reduction in the activity of SOD and GST enzymes in brain cells with increasing $\mathrm{MeHg}$ concentration (up to $10 \mathrm{mg} \mathrm{L}^{-1} \mathrm{MeHg}$ ).

The increase of the enzymes $\mathrm{Cu}, \mathrm{Zn}$-SOD, and Mn-SOD or $\gamma$-glutamylcysteine synthetase is the first adaptive response that cells present when exposed to mercury compounds [79]. However, 
studies in mice that were exposed to $\mathrm{Hg}$ and $\mathrm{MeHg}$ have shown that doses of these compounds reduce glutation and SOD levels, respectively, in liver and brain tissues [80,81]. These experimental results agree with the results shown in this study, and they would indicate that loggerhead turtle RBCs are as susceptible to oxidative stress that is caused by MeHg exposure as the brain cells of the fish [76], mouse, and insect neuronal and liver cells [79], since these same trends were observed for the activity of the SOD and GST enzymes, and lipid peroxidation.

The SOD and GST enzymes make up the first line of cellular defense against oxidative stress, neutralizing oxygen and nitrogen reactive species and preventing lipid peroxidation [20]. When the levels of these enzymes and other non-enzymatic antioxidants, such as cysteine, which participates in the uptake and release of mercury [79], are not intracellularly sufficient or their production levels reach maximum ceilings, their activity is reduced and metals and free radicals that could not be extracellularly expelled cause the degradation of PUFAS membrane and, therefore, lipid peroxidation [60].

$\mathrm{MeHg}$ is known to generate lipid peroxidation [82]. Studies have shown that long-lived species have erythrocyte cell membranes that are more resistant to lipid peroxidation, which might vary with the age of the individual and, therefore, be a direct predictor of survival [83]. In the present study, it was observed that the mean levels of MDA increased at 6 and $12 \mathrm{~h}$ of exposure, even though observed differences between exposure concentrations were not statistically significant due to the high variance of results. Apparently, the low number of individuals $(n=5)$ could explain this result. A positive correlation was observed between the concentration of $\mathrm{MeHg}$ and the levels of MDA, $\mathrm{r}=0.56, p<0.05$ after $12 \mathrm{~h}$ of exposure (Spearman). Studies with a higher $\mathrm{n}$ should be performed to verify this possible correlation due to the low number of samples used.

In this study, we found that an in vitro increase in $\mathrm{MeHg}$ concentration caused a corresponding increase in MDA concentration (LPO), as well as decreases in the activities of SOD and GST, result which is in agreement with previous studies $[76-78,84]$. Nonetheless, it is important to mention that there are other sensitive enzymes that respond to $\mathrm{MeHg}$ that should be studied as biomarkers of toxicity to mercury compounds. Peroxiredoxin and thioredoxins are found in all tissues and are involved in multiple functions that are associated with cellular maintenance and survival, including protein repair, regulation of the cell cycle, and cell signaling [85]. These enzymes could function in host defense against oxidative stress, modulate immune response, and control intracellular peroxide levels $[86,87]$, as well as participate in the antioxidant defense system [88,89].

Furthermore, it was reported for Chinese soft-shelled turtle (Pelodiscus sinensis) that peroxiredoxins was implicated defense against microbial pathogens and oxidants and would provide information of functional mechanism of immunity [90]. Studies that were carried out with these enzymes in human cell lines have reported that mercury and $\mathrm{MeHg}$ bind to their thiol groups (-SH), decreasing activity and causing inactivation in most cases [91-93]. Peroxiredoxins and thioredoxins are present in blood and, thus, are very important for living beings. They are very sensitive to oxidation [94,95], but, thanks to their plasticity, they have the ability of making post-translational modifications that prevent them from oxidizing, maintaining the homeostatic balance of cells [96]. Thioredoxins and peroxiredoxins function structurally and they have been barely studied in turtles [90]. Some of these studies have focused on evaluating how brevotoxins affect thioredoxin, GST, and SOD levels [97]. Moreover, turtles' regulation of intracellular levels of GST and peroxiredoxins has been studied under oxidative stress caused by anoxia, freezing, and exposure to lipopolysaccharides [98-100]. Overall, studies to date conclude that peroxiredoxins and thioredoxins are important targets for the compounds of mercury and their inhibition is likely to explain the results beyond Hg-induced toxicity [101]. For this reason, the evaluation in future studies of TrxR and Trx in blood and plasma could provide a useful tool for the prediction of adverse effects that are induced by mercury compounds.

Additionally, the results indicate that mercury can inhibit the activities of many proteins/enzymes that are involved in combating oxidative stress in cells, including thioredoxin ( $\operatorname{Tr} x)\left(\mathrm{MeHg}\right.$ and $\left.\mathrm{HgCl}_{2}\right)$, glutaredoxin (Grx) (MeHg) [91,102], glutathione peroxidase (Gpx) (MeHg) [103], glutathione reductase (GR) ( $\mathrm{MeHg}$ and $\mathrm{HgCl}_{2}$ ), thioredoxin reductase (TrxR) ( $\mathrm{MeHg}$ and $\mathrm{HgCl}_{2}$ ) [91,104], superoxide 
dismutase (SOD) ( $\mathrm{MeHg}$ and $\mathrm{HgCl}_{2}$ ) [105], neuronal nitric oxide synthase (nNOS) (MeHg) [105], and Keap1 [106]. In addition, mercury can also alter the ratio of GSH/glutathione disulfide (GSSH) either by directly binding to GSH, depleting GSH, or decreasing the levels of Gpx [102,107,108].

For species, such as sea turtles, where obtaining in vivo effect values is an impossibility, in vitro data provides a useful opportunity for conduct research into chemical risk to these species. As the field of sea turtle toxicology continues to expand, the results from studies such as this provide crucial information for the future experiments and guiding management and conservation plans [55].

It is necessary to improve the state of knowledge about the variability of indicators of oxidative stress in loggerhead turtles and their relationship to concentrations of $\mathrm{MeHg}$. For this purpose, the use of erythrocytes as biomarkers of environmental pollution is a promising, non-invasive, new tool for assessing the health status of this endangered species. This versatile and non-lethal monitoring tool might increase the usefulness of sea turtles as sentinel species, as indicators of the environmental health of their marine-coastal habitats in the light of spatial-temporal changes, and environmental degradation [69].

\section{Conclusions}

This is the first study that was conducted on loggerhead sea turtles, where the response of erythrocytes to MeHg-induced oxidative stress is evaluated. Erythrocytes resulted in being an excellent, simple, and inexpensive model to perform bioassays for ecotoxicological evaluation with heavy metals and other environmental pollutant molecules, specifically for MeHg in this study. Being loggerhead turtles considered a threatened or endangered species, RBCs represent an excellent ethical experimental in vitro model, allowing ecotoxicological studies to be carried out without the need to sacrifice animals. In addition, SOD, GST, and MDA were sensitive biomarkers of environmental pollution and oxidative stress in loggerhead turtles. However, these biomarkers presented high standard deviations due to the low number of individuals $(n=5)$ used. Future studies are suggested for carrying out further evaluations with a larger sample to improve the statistical significance of these results and confirm the benefits of these biomarkers as indicators of pollution and oxidative stress. It was observed that exposure to methylmercury in low concentrations induce protective redox defenses in RBCs, as seen from the induction of anti-oxidant enzyme SOD and GST activity. However, when the methylmercury concentration increases, these defenses are overcome and lipid peroxidation injury increases. Erythrocytes of loggerhead turtles in this study survived when kept in plasma in vacutainer tubes with Na-heparin at $4{ }^{\circ} \mathrm{C}$ for about eight weeks. This important characteristic allows for the use of these cells in sequential experiments.

Author Contributions: Conceptualization, J.H.-F. and E.A.L.-B.; methodology, J.H.-F., P.R.-B. and E.A.L.-B.; software, J.H.-F. and P.R.-B.; validation, J.H.-F., P.R.-B., L.M.-R., A.P.-V. and E.A.L.-B.; formal analysis, J.H.-F. and E.A.L.-B.; investigation, J.H.-F. and P.R.-B.; resources, J.H.-F., P.R.-B. and E.A.L.-B.; data curation, J.H.-F., P.R.-B., L.M.-R., A.P.-V. and E.A.L.-B.; writing-original draft preparation, J.H.-F. writing-review and editing, J.H.-F., P.R.-B., L.M.-R., A.P.-V. and E.A.L.-B.; supervision, E.A.L.-B., L.M.-R. and A.P.-V.; project administration, J.H.-F.; funding acquisition, J.H.-F., L.M.-R. and E.A.L.-B. All authors have read and agreed to the published version of the manuscript.

Funding: This work was supported by the Office of Research, Creation and Innovation of the Universidad Jorge Tadeo Lozano (340-07-10). Additional funding came from the Intramural Research Program of the National Institutes of Health (NIH, USA), National Library of Medicine (USA), National Center for Biotechnology Information (NCBI) ZIA LM082713-06. There was no additional external funding received for this study.

Acknowledgments: We are grateful to Rodadero Aquarium in Santa Marta for their collaboration in obtaining and providing samples of loggerhead for the development of this study. Samples were obtained under a research permit that was granted by the Ministry of Environment and Territorial Development (\#24 of 22 June 2012) Contract for Access to Genetic Resources (\#64 of 23 April 2013), and permit for the collection of samples of Colombian biodiversity, issued to the Jorge Tadeo Lozano University (Resolution 1271 of 23 October 2014, IDB040I File). The authors thank Michel Arhens for critical review of the manuscript.

Conflicts of Interest: The authors declare that they have no known competing financial interests or personal relationships that could have influenced the results reported in this paper. 


\section{References}

1. Finlayson, K.A.; Leusch, F.D.L.; Van De Merwe, J.P. The current state and future directions of marine turtle toxicology research. Environ. Int. 2016, 94, 113-123. [CrossRef]

2. Wallace, B.P.; Dimatteo, A.D.; Hurley, B.J.; Finkbeiner, E.M.; Alan, B.; Chaloupka, M.Y.; Hutchinson, B.J.; Abreu-grobois, F.A.; Marcovaldi, M.A.; Mortimer, J.A.; et al. Regional Management Units for Marine Turtles: A Novel Framework for Prioritizing Conservation and Research across Multiple Scales. PLoS ONE 2010, 5. [CrossRef] [PubMed]

3. Lancheros-piliego, D.; Fernández, J.H. AMDAR y PCR-extra-rápida para la identificación de la tortuga cabezona Caretta caretta (Testudines: Cheloniidae) utilizando el gen mitocondrial citocromo c oxidasa I (COI). Univ. Sci. 2013, 18. [CrossRef]

4. Day, R.D.; Segars, A.L.; Arendt, M.D.; Lee, A.M.; Peden-Adams, M.M. Relationship of blood mercury levels to health parameters in the loggerhead sea turtle (Caretta caretta). Environ. Health Perspect. 2007. [CrossRef] [PubMed]

5. Amorocho, D. Monitoring nesting loggerhead turtles (Caretta caretta) in the central Caribbean coast of Colombia. Mar. Turt. Newsl. 2003, 101, 8-13.

6. Jule, K.R.; Leaver, L.A.; Lea, S.E.G. The effects of captive experience on reintroduction survival in carnivores: A review and analysis. Biol. Conserv. 2008, 141, 355-363. [CrossRef]

7. Beyer, W.N.; Meador, J.P. Environmental Contaminants in Wildlife: Interpreting Tissue Concentrations; CRC Press: Boca Raton, FL, USA, 1996; pp. 1-768. [CrossRef]

8. Ley-quiñónez, C.; Zavala-norzagaray, A.A.; Espinosa-carreón, T.L.; Peckham, H. Baseline heavy metals and metalloid values in blood of loggerhead turtles ( Caretta caretta) from Baja California Sur, Mexico. Mar. Pollut. Bull. 2011, 62, 1979-1983. [CrossRef]

9. Yarsan, E.; Yipel, M. The Important Terms of Marine Pollution "Biomarkers and Biomonitoring. J. Mol. Biomark. Diagn. 2013, 1-4. [CrossRef]

10. Yipel, M.; Tekeli, İ.O.; İşler, C.T.; Altuğ, M.E. Heavy metal distribution in blood, liver and kidneys of Loggerhead (Caretta caretta) and Green (Chelonia mydas) sea turtles from the Northeast Mediterranean Sea. Mar. Pollut. Bull. 2017, 125, 487-491. [CrossRef]

11. Yang, L.; Zhang, Y.; Wang, F.; Luo, Z.; Guo, S.; Strähle, U. Toxicity of mercury: Molecular evidence. Chemosphere 2020, 245. [CrossRef]

12. Kotnik, J.; Horvat, M.; Begu, E.; Shlyapnikov, Y.; Sprovieri, F.; Pirrone, N. Dissolved gaseous mercury (DGM) in the Mediterranean Sea: Spatial and temporal trends. Mar. Chem. 2017, 193, 8-19. [CrossRef]

13. Burger, J.; Gochfeld, M. Mercury in canned tuna: White versus light and temporal variation. Environ. Res. 2004, 96, 239-249. [CrossRef] [PubMed]

14. Parra, J.P.; Betancourt, J.; Espinosa, L.F.; Garay, J. Evolución y estado de la contaminación por metales pesados y compuestos orgánicos en la Bahía de Cartagena, Colombia. Informe Técnico. Inf. Técnico 2011, 1-13.

15. Tosic, M.; Restrepo, J.D.; Lonin, S.; Izquierdo, A.; Martins, F. Water and sediment quality in Cartagena Bay, Colombia: Seasonal variability and potential impacts of pollution. Estuar. Coast. Shelf Sci. 2019, 216, 187-203. [CrossRef]

16. Selin, N.E.; Jacob, D.J.; Yantosca, R.M.; Strode, S.; Jaeglé, L.; Sunderland, E.M. Global 3-D land-ocean-atmosphere model for mercury: Present-day versus preindustrial cycles and anthropogenic enrichment factors for deposition. Glob. Biogeochem. Cycles 2008, 22, 1-13. [CrossRef]

17. Pirrone, N.; Cinnirella, S.; Feng, X.; Finkelman, R.B.; Friedli, H.R.; Leaner, J.; Mason, R.; Mukherjee, A.B.; Stracher, G.B.; Streets, D.G.; et al. Global mercury emissions to the atmosphere from anthropogenic and natural sources. Atmos. Chem. Phys. 2010, 10, 5951-5964. [CrossRef]

18. Farina, M.; Aschner, M.; Rocha, J.B.T. Oxidative stress in MeHg-induced neurotoxicity. Toxicol. Appl. Pharmacol. 2011, 256, 405-417. [CrossRef]

19. Joshi, D.; Kumar, M.D.; Kumar, A.; Sangeeta, S. Reversal of Methylmercury-Induced Oxidative Stress, Lipid Peroxidation, and DNA Damage by the Treatment of N-Acetyl Cysteine: A Protective Approach. J. Environ. Pathol. Toxicol. Oncol. 2014, 33, 167-182. [CrossRef]

20. Rodríguez, M.; Osuna, A. Efecto de la adición de antioxidantes sobre la motilidad espermática post-criopreservación y fertilidad del semen de peces. Rev. Vet. 2017, 28, 157-164. 
21. Franco, R.; Navarro, G.; Mart, E. Antioxidant defense mechanisms in erythrocytes and in the central nervous system. Antioxidants 2019, 8, 46. [CrossRef]

22. Orson, R.; Brncunn, L. Uptake of methyl mercuric chloride and mercuric chloride by trout: A sturly of uptake pathways into the whotre anirnal and uptake by erythrocytes in vitro. J. Fish. Board Can. 1973, 30, 1293-1299. [CrossRef]

23. Pagano, M.; Faggio, C. The use of erythrocyte fragility to assess xenobiotic cytotoxicity. Cell Biochem. Funct. 2015, 33, 351-355. [CrossRef] [PubMed]

24. Massarsky, A.; Abraham, R.; Nguyen, K.C.; Rippstein, P.; Tayabali, A.F.; Trudeau, V.L.; Moon, T.W. Nanosilver cytotoxicity in rainbow trout (Oncorhynchus mykiss) erythrocytes and hepatocytes. Comp. Biochem. Physiol. Part C Toxicol. Pharmacol. 2014, 159, 10-21. [CrossRef] [PubMed]

25. Gabryelak, T.; Piatkowska, M.; Leyko, W.P.G. Seasonal variations in the activities of peroxide metabolism enzymes in erythrocytes of freshwater fish species. Comp. Biochem. Physiol. Part C Toxicol. Pharmacol. 1983, 75, 383-385. [CrossRef]

26. Goodchild, C.G.; DuRant, S.E. Fluorescent heme degradation products are biomarkers of oxidative stress and linked to impaired membrane integrity in avian red blood cells. Physiol. Biochem. Zool. 2020, 93, 129-139. [CrossRef]

27. Velando, A.; Noguera, J.C.; da Silva, A.; Kim, S.Y. Redox-regulation and life-history trade-offs: Scavenging mitochondrial ROS improves growth in a wild bird. Sci. Rep. 2019, 9, 1-9. [CrossRef]

28. Sakuragui, M.M.; Paulino, M.G.; da Silva e Souza, N.E.; Tavares, D.; Terezan, A.P.; Pesenti, E.; Giani, A.; Fernandes, J.B.; Cestari, M.M.; Fernandes, M.N. Crude extract of cyanobacterium Radiocystis fernandoi strain R28 induces anemia and oxidative stress in fish erythrocytes. Toxicon 2019, 169, 18-24. [CrossRef]

29. Cortés-Gutiérrez, E.I.; García-Salas, J.A.; Dávila-Rodríguez, M.I.; Ceyca-Contreras, J.P.; González-Ramírez, E.G. Evaluation of oxidative DNA damage in pigeon erythrocytes using DNA breakage detection-fluorescence in situ hybridization (DBD-FISH). Biotech. Histochem. 2019, 94, 600-605. [CrossRef]

30. Burgos-Aceves, M.A.; Lionetti, L.; Faggio, C. Multidisciplinary haematology as prognostic device in environmental and xenobiotic stress-induced response in fish. Sci. Total Environ. 2019, 670, 1170-1183. [CrossRef]

31. Panghal, A.; Sathua, K.B.; Flora, S.J.S. Gallic acid and MiADMSA reversed arsenic induced oxidative/nitrosative damage in rat red blood cells. Heliyon 2020, 6, e03431. [CrossRef]

32. Hammami, N.; Athmouni, K.; Lahmar, I.; Ben Abdallah, F.; Belghith, K. Antioxidant potential of Salicornia arabica lipid extract and their protective effect against cadmium induced oxidative stress in erythrocytes isolated from rats. J. Food Meas. Charact. 2019, 13, 2705-2712. [CrossRef]

33. Agrawal, D.; Sultana, P.; Gupta, G.S.D. Oxidative damage and changes in the glutathione redox system in erythrocytes from rats treated with hexachlorocyclohexane. Food Chem. Toxicol. 1991, 29, 459-462. [CrossRef]

34. Barraza, A.D.; Komoroske, L.M.; Allen, C.; Eguchi, T.; Gossett, R.; Holland, E.; Lawson, D.D.; LeRoux, R.A.; Long, A.; Seminoff, J.A.; et al. Trace metals in green sea turtles (Chelonia mydas) inhabiting two southern California coastal estuaries. Chemosphere 2019, 223, 342-350. [CrossRef] [PubMed]

35. Çördük, N.; Doğru, N.H.; Gül, Ç.; Tosunoğlu, M. Assessment of nuclear abnormalities in erythrocytes of balkan pond turtle Mauremys rivulata (Valenciennes, 1833) (Testudines: Geoemydidae) from the Biga Stream, Çanakkale, Turkey. Acta Zool. Bulg. 2019, 71, 219-226.

36. Aguirre, A.A.; Balazs, G.H. Comparative Original Article Blood Biochemistry Values of Green Turtles, Chelonia Mydas, With and Without Fibropapillomatosis. Comp. Haematol. Int. 2000, 10, 132-137. [CrossRef]

37. Bjorndal, K.A.; Bolten, A.B.; Martins, H.R. Somatic growth model of juvenile loggerhead sea turtles Caretta caretta: Duration of pelagic stage. Mar. Ecol. Prog. Ser. 2000, 202, 265-272. [CrossRef]

38. Dutton, P.H. Methods for collection and preservation of samples for sea turtle genetic studies. In Proceedings of the International Symposium on Sea Turtle Conservation Genetics, Miami, FL, USA, 1 January 1996.

39. Finney, D.T. Probit Analysis; Cambridge University Press: Cambridge, UK, 1971.

40. Venables, W.N.; Ripley, B.D. Modern Applied Statistics with S; Springer Science \& Business Media: New York, NY, USA, 2002.

41. Guisande, C.; Heine, J.; González-DaCosta, J.; García-Roselló, E. RWizard Software; University of Vigo: Vigo, Spain, 2014. 
42. Martins, R.D.P.; Braga, H.D.C.; Aline, P.; Dalmarco, J.B.; De Bem, A.F.; Roberto, A.; Santos, S.; Dafre, A.L.; Pizzolatti, M.G.; Latini, A.; et al. Synergistic neurotoxicity induced by methylmercury and quercetin in mice. Food Chem. Toxicol. 2009, 47, 645-649. [CrossRef]

43. Habig, W.H.; Pabst, M.J.; Jakoby, W.B. Glutathione S-Transferases The First Enzymatic Step In Mercapturic Acid Formation. J. Biol. Chem. 2005, 249, 7130-7139.

44. R Development Core Team, R. A Language and Environment for Statistical Computing; R Foundation for Statistical Computing: Copenhagen, Denmark, 2017; p. 900051.

45. Casal, A.B.; Luis, F.L.; Juste, C.; Or, J. Comparative study of hematologic and plasma biochemical variables in Eastern Atlantic juvenile and adult nesting loggerhead sea turtles (Caretta caretta). Vet. Clin. Pathol. 2009, 2, 213-218. [CrossRef]

46. Deem, S.L.; Norton, T.M.; Mitchell, M.; Segars, A.; Alleman, A.R.; Cray, C.; Poppenga, R.H.; Dodd, M.; Karesh, W.B. Comparison of blood values in foraging, nesting, and stranded loggerhead turtles (Caretta caretta) along the coast of Georgia, USA. J. Wildl. Dis. 2009, 45, 41-56. [CrossRef]

47. Yang, T.; Haas, H.L.; Patel, S.; Smolowitz, R.; James, M.C.; Williard, A.S. Blood biochemistry and haematology of migrating loggerhead turtles (Caretta caretta) in the Northwest Atlantic: Reference intervals and intra-population comparisons. Conserv. Physiol. 2019, 7, 1-15. [CrossRef] [PubMed]

48. Rousselet, E.; Stacy, N.I.; LaVictoire, K.; Higgins, B.M.; Tocidlowski, M.E.; Flanagan, J.P.; Godard-Codding, C.A. Hematology and plasma biochemistry analytes in five age groups of immature, captive-reared loggerhead sea turtles ( Caretta caretta). J. Zoo Wildl. Med. 2013, 44, 859-874. [CrossRef] [PubMed]

49. Angeles, M.; Morcillo, P.; Cuesta, A. In vitro effects of metals on isolated head-kidney and blood leucocytes of the teleost fi sh Sparus aurata L. and Dicentrarchus labrax L. Fish Shellfish Immunol. 2016, 54. [CrossRef]

50. Lutz, P.L.; Dunbar-Cooper, A.N.N. The loggerhead sea turtle, Caretta Caretta. Fish. Bull. 1971, 85, 37.

51. Kelly, T.R.; McNeill, J.B.; Avens, L.; Hall, A.G.; Goshe, L.R.; Hohn, A.A.; Godfrey, M.H.; Nicole Mihnovets, A.; Cluse, W.M.; Harms, C.A. Clinical pathology reference intervals for an in-water population of juvenile loggerhead sea turtle s (Caretta caretta) in Core Sound, North Carolina, USA. PLoS ONE 2015, 10, 1-13. [CrossRef] [PubMed]

52. Flint, M.; Morton, J.M.; Limpus, C.J.; Patterson-Kane, J.C.; Mills, P.C. Reference intervals for plasma biochemical and hematologic measures in loggerhead sea turtles (Caretta caretta) from Moreton bay Australia. J. Wildl. Dis. 2010, 46, 731-741. [CrossRef] [PubMed]

53. Ruggiero, M.G.; Ferretti, L.; Glomski, C.; Federico, N. Erythrophagocytosis in Circulating Blood of Loggerhead Turtles Caretta caretta: The Pitting of Heinz Bodies. J. Exp. Zool. 2013. [CrossRef]

54. Figueres, J. Estudio Sanitario de las Tortugas Terrestres Mediterráneas (Género Testudo) e Implicaciones Para su Conservación; Universidad Autonoma de Barcelona: Barcelona, Spain, 2015; pp. 1-187.

55. Finlayson, K.A.; Leusch, F.D.L.; Van De Merwe, J.P. Science of the Total Environment Cytotoxicity of organic and inorganic compounds to primary cell cultures established from internal tissues of Chelonia mydas. Sci. Total Environ. 2019, 664, 958-967. [CrossRef]

56. Olivero-verbel, J.; Caballero-gallardo, K.; Torres, N. International Journal of Environmental Assessment of mercury in muscle of fish from Cartagena Bay, a tropical estuary at the north of Colombia. Int. J. Environ. Health Res. 2009, 5, 37-41. [CrossRef]

57. Stricks, W.; Kolthoff, I.M. Reactions between Mercuric Mercury and Cysteine and Glutathione. Apparent Dissociation Constants, Heats and Entropies of Formation of Various Forms of Mercuric Mercapto-Cysteine and -Glutathione. J. Am. Chem. Soc. 1953, 75, 5673-5681. [CrossRef]

58. Weed, R.; Eber, J.; Biology, R. Interaction of Mercury with Human Erythrocytes. J. Gen. Physiol. 1962, 45, 395-410. [CrossRef] [PubMed]

59. Naganuma, A.; Koyama, Y.; Imura, N. Behavior of Methylmercury in Mammalian Erythrocytes. Toxicol. Appl. Pharmacol. 1980, 410, 405-410. [CrossRef]

60. Farina, M.; Aschner, M. Methylmercury-Induced Neurotoxicity: Focus on Pro-oxidative Events and Related Consequences. In Neurotoxicity of Metals; Aschner, M., Costa, L.G., Eds.; Springer International Publishing: Cham, Switzerland, 2017; pp. 267-286, ISBN 978-3-319-60189-2.

61. Zapata, L.M.; Bock, B.C.; Yaneth, L.; Palacio, J.A. Ecotoxicology and environmental fafety application of the micronucleus test and comet assay in Trachemys callirostris erythrocytes as a model for in situ genotoxic monitoring. Ecotoxicol. Environ. Saf. 2016, 127, 108-116. [CrossRef] [PubMed] 
62. Cocci, P.; Capriotti, M.; Mosconi, G.; Palermo, F.A. Effects of endocrine disrupting chemicals on estrogen receptor alpha and heat shock protein 60 gene expression in primary cultures of loggerhead sea turtle (Caretta caretta) erythrocytes ir. Environ. Res. 2017, 158, 616-624. [CrossRef] [PubMed]

63. Tan, F.; Wang, M.; Wang, W.; Alonso Aguirre, A.; Lu, Y. Validation of an in vitro cytotoxicity test for four heavy metals using cell lines derived from a green sea turtle (Chelonia mydas). Cell Biol. Toxicol. 2010, 26, 255-263. [CrossRef] [PubMed]

64. Tong, J.; Wang, Y.; Lu, Y. In vitro evaluation of inorganic and methyl mercury mediated cytotoxic effect on neural cells derived from different animal species. J. Environ. Sci. 2016, 41, 138-145. [CrossRef]

65. Young, J.L.; Wise, S.S.; Xie, H.; Zhu, C.; Fukuda, T.; Wise, J.P. Comparative cytotoxicity and genotoxicity of soluble and particulate hexavalent chromium in human and hawksbill sea turtle (Eretmochelys imbricata) skin cells. Comp. Biochem. Physiol. Part C Toxicol. Pharmacol. 2015, 178, 145-155. [CrossRef]

66. Kaska, Y.; Furness, R.W. Heavy metals in marine turtle eggs and hatchlings in the mediterranean. Zool. Middle East 2001, 24, 127-132. [CrossRef]

67. Kampalath, R.; Gardner, S.C.; Méndez-Rodríguez, L.; Jay, J.A. Total and methylmercury in three species of sea turtles of Baja California Sur. Mar. Pollut. Bull. 2006, 52, 1816-1823. [CrossRef]

68. Mcgraw, K.J.; Cohen, A.A.; Costantini, D.; Ho, P. The ecological significance of antioxidants and oxidative stress: A marriage between mechanistic and functional perspectives. Funct. Ecol. 2010, 2000, 947-949. [CrossRef]

69. Labrada-martagón, V.; Rodríguez, P.A.T.; Méndez-rodríguez, L.C.; Zenteno-savín, T. Comparative Biochemistry and Physiology, Part C Oxidative stress indicators and chemical contaminants in East Paci fi c green turtles (Chelonia mydas) inhabiting two foraging coastal lagoons in the Baja California peninsula. Comp. Biochem. Physiol. Part C: Toxicol. Pharmacol. 2011, 154, 65-75. [CrossRef]

70. Perrault, J.R.; Schmid, J.R.; Walsh, C.J.; Yordy, J.E.; Tucker, A.D. Brevetoxin exposure, superoxide dismutase activity and plasma protein electrophoretic profiles in wild-caught Kemp's ridley sea turtles (Lepidochelys kempii) in southwest Florida. Harmful Algae 2014, 37, 194-202. [CrossRef]

71. Finlayson, K.A.; Leusch, F.D.L.; Van De Merwe, J.P. Primary green turtle (Chelonia mydas) skin fibroblasts as an in vitro model for assessing genotoxicity and oxidative stress. Aquat. Toxicol. 2018. [CrossRef] [PubMed]

72. Isaji, Y.; Okochi, M.; Horio, F.; Honda, H. Use of erythrocyte adhesion assay to predict the risk of diabetic complications. Biochem. Eng. J. 2009, 43, 178-184. [CrossRef]

73. Schara, M.; Nemec, M.; Falnoga, I.; Kobal, A.B.; Kveder, M.; Svetek, J. The action of mercury on cell membranes. Cell. Mol. Biol. Lett. 2001, 6, 299-304. [PubMed]

74. Cortés-Gómez, A.A.; Romero, D.; Girondot, M. The current situation of inorganic elements in marine turtles: A general review and meta-analysis. Environ. Pollut. 2017, 229, 567-585. [CrossRef]

75. Salvarani, P.I.; Vieira, L.R.; Ku-Peralta, W.; Morgado, F.; Osten, J.R. Von Oxidative stress biomarkers and organochlorine pesticides in nesting female hawksbill turtles Eretmochelys imbricata from Mexican coast (Punta Xen, Mexico). Environ. Sci. Pollut. Res. 2018, 25, 23809-23816. [CrossRef]

76. Berntssen, M.H.G.; Aatland, A.; Handy, R.D. Chronic dietary mercury exposure causes oxidative stress, brain lesions, and altered behaviour in Atlantic salmon (Salmo salar) parr. Aquat. Toxicol. 2003, 65. [CrossRef]

77. Zaman, K.; Macgill, R.S.; Johnson, J.E.; Ahmad, S.; Pardini, R.S. An Insect Model for Assessing Mercury Toxicity: Effect of Mercury on Antioxidant Enzyme Activities of the Housefly (Musca domestica) and the Cabbage Looper Moth (Trichoplusia ni). Arch. Environ. Contam. Toxicol. 1994, 118, 114-118. [CrossRef]

78. Hirota, Y.; Yamaguchi, S.; Shimojoh, N.; Sano, K.I. Inhibitory effect of methylmercury on the activity of glutathione peroxidase. Toxicol. Appl. Pharmacol. 1980, 176, 174-176. [CrossRef]

79. Kumagai, Y.; Shinyashiki, M.; Shimojo, N. Alterations in Superoxide Dismutase Isozymes by Methylmercury. Appl. Organomet. Chem. 1997, 11, 635-643. [CrossRef]

80. Lund, B.; Miller, M.; Woodst, S. Studies on $\mathrm{Hg}$ (II) -Induced $\mathrm{H}_{2} \mathrm{O}_{2}$ formation and oxidative stress in vivo and in vitro in rat. Biochmdcal Phamwcology. 2017, 45, 2017-2024.

81. Yee, S.; Choi, B. Methylmercury poisoning induces oxidative stress in the mouse brain. Exp. Mol. Pathol. 1994, 60, 188-196. [CrossRef] [PubMed]

82. Clarkson, T.W. The Toxicology of Mercury and Its Chemical Compounds. Crit. Rev. Toxicol. 2006, 36, 609-662. [CrossRef] [PubMed]

83. Stier, A.; Reichert, S.; Criscuolo, F.; Bize, P. Red blood cells open promising avenues for longitudinal studies of ageing in laboratory, non-model and wild animals. Exp. Gerontol. 2015, 71, 118-134. [CrossRef] [PubMed] 
84. Tanaka, R.; Nakai, K.; Nakai, K. Hemolysis and morphological changes in rat erythrocytes with mercurials. Jpn. J. Pharmacol. 1977, 27, 413-419. [CrossRef]

85. Lillig, C.H.; Holmgren, A. Thioredoxin and Related Molecules-From Biology to Health and Disease. Antioxid. Redox Signalin 2006, 9, 25-47. [CrossRef]

86. Hall, A.; Karplus, P.A.; Poole, L.B. Typical 2-Cys peroxiredoxins - Structures, mechanisms and functions. FEBS J. 2009, 276, 2469-2477. [CrossRef]

87. Perkins, A.; Nelson, K.J.; Parsonage, D.; Poole, L.B.; Karplus, P.A. Peroxiredoxins: Guardians against oxidative stress and modulators of peroxide signaling. Trends Biochem. Sci. 2015, 40, 435-445. [CrossRef]

88. Arnér, E.S.J. Focus on mammalian thioredoxin reductases-Important selenoproteins with versatile functions. Biochim. Biophys. Acta (BBA)-Gen. Subj. 2009, 1790, 495-526. [CrossRef]

89. Winterbourn, C.C. The Biological Chemistry of Hydrogen Peroxide, 1st ed.; Elsevier Inc.: Amsterdam, The Netherlands, 2013; Volume 528, ISBN 9780124058811.

90. Zhang, Y.; Mi, K.; Ding, X.; Li, Y.; Wang, T.; Dou, T.; Ding, J.; Wei, W. Characterization of a classical 2-cysteine peroxiredoxin1 gene from Chinese soft-shelled turtle Pelodiscus sinensis with its potent antioxidant properties and putative immune response. Dev. Comp. Immunol. 2019. [CrossRef] [PubMed]

91. Carvalho, C.M.L.; Chew, E.; Hashemy, S.I.; Lu, J. Inhibition of the Human Thioredoxin System. J. Biol. Chem. 2008, 283, 11913-11923. [CrossRef] [PubMed]

92. Farina, M.; Avila, D.S.; Da Rocha, J.B.T.; Aschner, M. Metals, oxidative stress and neurodegeneration: A focus on iron, manganese and mercury. Neurochem. Int. 2013, 62, 575-594. [CrossRef] [PubMed]

93. Maniero, M.Á.; Wuilloud, R.G.; Callegari, E.A.; Smichowski, P.N.; Fanelli, M.A. Metalloproteomics analysis in human mammary cell lines treated with inorganic mercury. J. Trace Elem. Med. Biol. 2020, 58, 126441. [CrossRef]

94. Liu, D.L.; Zhao, L.X.; Zhang, S.; Du, J.R. Peroxiredoxin 1-mediated activation of TLR4/NF-kB pathway contributes to neuroinflammatory injury in intracerebral hemorrhage. Int. Immunopharmacol. 2016, 41, 82-89. [CrossRef] [PubMed]

95. Poynton, R.A.; Hampton, M.B. Peroxiredoxins as biomarkers of oxidative stress. Biochim. Biophys. Acta (BBA)-Gen. Subj. 2014, 1840, 906-912. [CrossRef]

96. Immenschuh, S.; Baumgart-Vogt, E. Peroxiredoxins, oxidative stress, and cell proliferation. Antioxid. Redox Signal. 2005, 7, 768-777. [CrossRef]

97. Walsh, C.J.; Cocilova, C.; Restivo, J.; Flewelling, L.; Milton, S. Immune function in Trachemys scripta following exposure to a predominant brevetoxin congener, $\mathrm{PbTx}-3$, as a model for potential health impacts for sea turtles naturally exposed to brevetoxins. Ecotoxicol 2019, 28, 1085-1104. [CrossRef]

98. Krivoruchko, A.; Storey, K.B. Activation of antioxidant defenses in response to freezing in freeze-tolerant painted turtle hatchlings. Biochim. Biophys. Acta (BBA)-Gen. Subj. 2010. [CrossRef]

99. Storey, K.B. Reptile freeze tolerance: Metabolism and gene expression. Cryobiology 2006, 52, 1-16. [CrossRef]

100. Xu, J.; Zhao, J.; Li, Y.; Zou, Y.; Lu, B.; Chen, Y.; Ma, Y.; Xu, H. Evaluation of differentially expressed immune-related genes in intestine of Pelodiscus sinensis after intragastric challenge with lipopolysaccharide based on transcriptome analysis. Fish Shellfish Immunol. 2016. [CrossRef] [PubMed]

101. Branco, V.; Ramos, P.; Canário, J.; Lu, J.; Holmgren, A.; Carvalho, C. Biomarkers of adverse response to mercury: Histopathology versus thioredoxin reductase activity. BioMed Res. Int. 2012, 2012. [CrossRef]

102. Robitaille, S.; Mailloux, R.J.; Man, H. Methylmercury alters glutathione homeostasis by inhibiting glutaredoxin 1 and enhancing glutathione biosynthesis in cultured human astrocytoma cells. Toxicol. Lett. 2016, 256, 1-10. [CrossRef] [PubMed]

103. Farina, M.; Campos, F.; Vendrell, I.; Berenguer, J.; Barzi, M. Probucol Increases Glutathione Peroxidase-1 Activity and Displays Long-Lasting Protection against Methylmercury Toxicity in Cerebellar Granule Cells. Toxicol. Sci. 2009, 112, 416-426. [CrossRef] [PubMed]

104. Carvalho, C.M.L.; Lu, J.; Zhang, X.; Arne, E.S.J.; Effects, A. Effects of selenite and chelating agents on mammalian thioredoxin reductase inhibited by mercury: Implications for treatment of mercury poisoning. FASEB J. 2010, 25, 370-381. [CrossRef]

105. Shinyashiki, M.; Kumagai, Y.; Homma-Takeda, S.; Nagafune, J.; Shimojo, N. Selective inhibition of the mouse brain Mn-SOD by methylmercury. Environ. Toxicol. Pharmacol. 1996, 2, 359-366. [CrossRef] 
106. Toyama, T.; Sumi, D.; Shinkai, Y.; Yasutake, A.; Taguchi, K.; Tong, K.I.; Yamamoto, M.; Kumagai, Y. Cytoprotective role of Nrf2 / Keap1 system in methylmercury toxicity. Biochem. Biophys. Res. Commun. 2007, 363, 645-650. [CrossRef]

107. Messer, R.L.W.; Lockwood, P.E.; Tseng, W.Y.; Edwards, K.; Shaw, M.; Caughman, G.B.; Lewis, J.B.; Wataha, J.C.; College, M. Mercury (II) alters mitochondrial activity of monocytes at sublethal doses via oxidative stress mechanisms. J. Biomed. Mater. Res. Part B 2005, 257-263. [CrossRef]

108. Wataha, J.C.; Lewis, J.B.; Mccloud, V.V.; Shaw, M.; Omata, Y.; Lockwood, P.E.; Messer, R.L.W.; Hansen, J.M. Effect of mercury (II) on Nrf2, thioredoxin reductase-1 and thioredoxin-1 in human monocytes. Dent. Mater. 2007, 24, 765-772. [CrossRef]

(C) 2020 by the authors. Licensee MDPI, Basel, Switzerland. This article is an open access article distributed under the terms and conditions of the Creative Commons Attribution (CC BY) license (http://creativecommons.org/licenses/by/4.0/). 